\title{
Biomass burning aerosols and the low-visibility events in Southeast Asia
}

\author{
Hsiang-He Lee ${ }^{1}$, Rotem Z. Bar-Or ${ }^{2}$, and Chien Wang ${ }^{1,2}$ \\ ${ }^{1}$ Center for Environmental Sensing and Modeling, Singapore-MIT Alliance for Research and Technology, Singapore \\ ${ }^{2}$ Center for Global Change Science, Massachusetts Institute of Technology, Cambridge, MA, USA \\ Correspondence to: Hsiang-He Lee (hsiang-he@smart.mit.edu)
}

Received: 14 June 2016 - Published in Atmos. Chem. Phys. Discuss.: 20 June 2016

Revised: 13 December 2016 - Accepted: 29 December 2016 - Published: 23 January 2017

\begin{abstract}
Fires including peatland burning in Southeast Asia have become a major concern to the general public as well as governments in the region. This is because aerosols emitted from such fires can cause persistent haze events under certain weather conditions in downwind locations, degrading visibility and causing human health issues. In order to improve our understanding of the spatiotemporal coverage and influence of biomass burning aerosols in Southeast Asia, we have used surface visibility and particulate matter concentration observations, supplemented by decade-long (2003 to 2014) simulations using the Weather Research and Forecasting (WRF) model with a fire aerosol module, driven by high-resolution biomass burning emission inventories. We find that in the past decade, fire aerosols are responsible for nearly all events with very low visibility $(<7 \mathrm{~km})$. Fire aerosols alone are also responsible for a substantial fraction of low-visibility events (visibility $<10 \mathrm{~km}$ ) in the major metropolitan areas of Southeast Asia: up to $39 \%$ in Bangkok, $36 \%$ in Kuala Lumpur, and $34 \%$ in Singapore. Biomass burning in mainland Southeast Asia accounts for the largest contribution to total fire-produced $\mathrm{PM}_{2.5}$ in Bangkok (99\%), while biomass burning in Sumatra is a major contributor to fire-produced $\mathrm{PM}_{2.5}$ in Kuala Lumpur (50\%) and Singapore (41\%). To examine the general situation across the region, we have further defined and derived a new integrated metric for 50 cities of the Association of Southeast Asian Nations (ASEAN): the haze exposure day (HED), which measures the annual exposure days of these cities to low visibility $(<10 \mathrm{~km})$ caused by particulate matter pollution. It is shown that HEDs have increased steadily in the past decade across cities with both high and low populations. Fire events alone are found to be responsible for up to about half of the total HEDs. Our re-
\end{abstract}

sults suggest that in order to improve the overall air quality in Southeast Asia, mitigation policies targeting both biomass burning and fossil fuel burning sources need to be implemented.

\section{Introduction}

In recent decades, biomass burning has become frequent and widespread across mainland Southeast Asia and the islands of Sumatra and Borneo (Langner et al., 2007; Carlson et al., 2012; Page et al., 2002; van der Werf et al., 2010). Abundant aerosols emitted from such fires cause haze events to occur in downwind locations such as Singapore (Koe et al., 2001; Heil et al., 2007; See et al., 2006), degrading visibility and threatening human health (Emmanuel, 2000; Kunii et al., 2002; Johnston et al., 2012; Mauderly and Chow, 2008; Crippa et al., 2016). Besides causing air quality issues, the fire aerosols contain rich carbonaceous compounds such as black carbon (BC) (Fujii et al., 2014) and thus can reduce sunlight through both absorption and scattering. Indirect effects of fire aerosols on the climate are even more complicated due to various cloud types and meteorological conditions in the Maritime Continent (MC) (Sekiguchi et al., 2003; Lin et al., 2013; Wu et al., 2013; Grandey et al., 2016).

The majority of present-day fires in Southeast Asia occur due to human interference such as land clearing for oil palm plantations, other causes of deforestation, poor peatland management, and burning of agriculture waste (Dennis et al., 2005; Marlier et al., 2015a). Certain policies and regulations, such as those regarding migration, also affect the occurrence of burning events. Large fires have occurred since the 1960s 
in Sumatra; however, the first fire event in Kalimantan happened in the 1980s (Field et al., 2009). Based on economic incentives and population growth in Southeast Asia, future land-use management will play an important role in determining the occurrence of fires across the region (Carlson et al., 2012; Marlier et al., 2015b).

Besides human interventions, meteorological factors can also influence fire initiation, intensity, and duration (Reid et al., 2012, 2015). Of particular importance is rainfall. Reid et al. (2012) investigated relationships between fire hotspot appearance and various weather phenomena as well as climate variabilities in different timescales over the MC, including: (1) the El Niño-Southern Oscillation (ENSO) (Rasmusson and Wallace, 1983; McBride et al., 2003) and the Indian Ocean Dipole (IOD) (Saji et al., 1999); (2) seasonal migration of the Inter-tropical Convergence Zone (ITCZ) and associated Southeast Asia monsoons (Chang et al., 2005); (3) intra-seasonal variability associated with the Madden-Julian Oscillation (MJO) (Madden and Julian, 1971; Zhang, 2005) and the west Sumatran low (Wu and Hsu, 2009); (4) equatorial waves, mesoscale features, and tropical cyclones; and (5) convection. One interesting finding is that the influence of these factors on fire events varies over different parts of the MC. For example, the fire signal in one part of Kalimantan is strongly related to both the monsoons and ENSO. In contrast, fire activity in Central Sumatra is closely tied to neither the monsoons nor ENSO, but is closely tied to the MJO.

Climate variability of meteorological phenomena affects not only biomass burning emissions but also transport of fire aerosols (Reid et al., 2012). The seasonal migration of the ITCZ and the associated monsoonal circulation dominate seasonal wind flows, whereas sea breezes, tropical cyclones, and topography determine air flow on smaller spatial and temporal scales - all these phenomena play significant roles in determining the transport pathway of fire aerosols (Wang et al., 2013). For example, the intense haze episode of June 2013, a long-lasting event with a "very unhealthy" air pollution level in Singapore, was actually caused by enhanced fire aerosol transport from Sumatra to West Malaysia owing to a tropical cyclone located in South China Sea. Recently, using a global chemistry transport model combined with a back-trajectory tracer model, Reddington et al. (2014) attempted to attribute particulate pollution in Singapore to different burning sites in surrounding regions over a short time period of 5 years. The coarse $2.8^{\circ}$ resolution model used in the study, however, has left many open questions.

In this study, we aim to examine and quantify the impact of fire aerosols on the visibility and air quality of Southeast Asia over the past decade. Analyses of observational data and comprehensive regional model results have both been performed in order to improve our understanding of this issue. We first describe methodologies adopted in the study, followed by the results and findings from our assessment of the fire aerosol on the degradation of visibility in several selected cities and also over the whole of Southeast Asia. We then
Table 1. WRF physics scheme configuration.

\begin{tabular}{ll}
\hline Physics processes & Scheme \\
\hline microphysics & Morrison (2 moments) scheme \\
long-wave radiation & rrtmg scheme \\
shortwave radiation & rrtmg scheme \\
surface layer & MYNN surface layer \\
land surface & Unified Noah land-surface model \\
planetary boundary layer & MYNN 2.5 level TKE scheme \\
cumulus parameterization & Grell-Freitas ensemble scheme \\
\hline
\end{tabular}

discuss the sensitivity of our findings to the use of different meteorological datasets as well as fire emission inventories. The last section summarizes and concludes our work.

\section{Methodology}

\subsection{The model}

In this study, we have used the Weather Research And Forecasting (WRF) model coupled with a chemistry component (WRF-Chem) version 3.6 (Grell et al., 2005). Our focus in this study is on the fire aerosol life cycle. Therefore, we chose to use WRF-Chem with a modified chemical tracer module instead of a full chemistry package to model the fire $\mathrm{PM}_{2.5}$ particles as tracers without involving much more complicated gaseous and aqueous chemical processing calculations but including dry and wet depositions. Emissions of other chemical species were excluded in the simulations. This configuration lowers the computational burden substantially, and thus allows us to conduct long model integrations to determine the contributions of fire aerosol to the degradation of visibility in the region over the past decade. In WRFChem, the sinks of $\mathrm{PM}_{2.5}$ particles include dry deposition and wet scavenging calculated at every time step. The simulations are employed within a model domain with a horizontal resolution of $36 \mathrm{~km}$, including $432 \times 148$ horizontal grid points (Fig. 1), and 31 vertically staggered layers that are stretched to have a higher resolution near the surface (an average depth of $\sim 30 \mathrm{~m}$ in the first model half layer) based on a terrain-following pressure coordinate system. The time step is $180 \mathrm{~s}$ for advection and physics calculation. The physics schemes adopted in the simulations are listed in Table 1 . The initial and boundary meteorological conditions are taken from reanalysis meteorological data. In order to examine the potential influence of different reanalysis products on simulation results, we have used two such datasets: (1) the National Center for Environment Prediction FiNal (NCEPFNL) reanalysis data (National Centers for Environmental Prediction, 2000), which has a spatial resolution of $1^{\circ}$ and a temporal resolution of $6 \mathrm{~h}$, and (2) ERA-Interim, which is a global atmospheric reanalysis from the European Centre for Medium-Range Weather Forecasts (ECMWF) (Eu- 


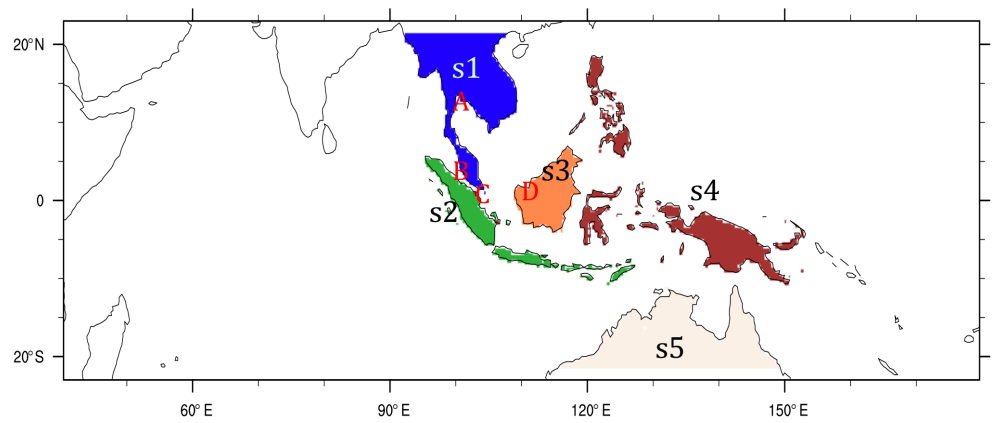

Figure 1. Model domain used for simulations. The domain has $432 \times 148$ grid points with a horizontal resolution of $36 \mathrm{~km}$. Five fire source regions marked in different colors and labeled as s1, s2, s3, s4, and s5 represent mainland Southeast Asia (s1), Sumatra, and the Java islands (s2), Borneo (s3), the rest of Maritime Continent (s4), and northern Australia (s5). A, B, C, and D indicate the location of four selected cities: Bangkok (A), Kuala Lumpur (B), Singapore (C), and Kuching (D).

ropean Centre for Medium-Range Weather, 2009), providing 6-hourly atmospheric fields on sixty pressure levels from surface to $0.1 \mathrm{hPa}$ with a horizontal resolution of approximately $80 \mathrm{~km}$. Sea surface temperature is updated every $6 \mathrm{~h}$ in both NCEP-FNL and ERA-Interim. All simulations used four-dimensional data assimilation (FDDA) to nudge NCEPFNL or ERA-Interim temperature, water vapor, and zonal as well as meridional wind speeds above the planetary boundary layer (PBL). This approach has been shown to provide realistic temperature, moisture, and wind fields in a long simulation (Stauffer and Seaman, 1994).

Two biomass burning emission inventories were also used in this study to investigate the sensitivity of modeled fire aerosol concentration to different emission estimates. The first emission inventory is the Fire Inventory from NCAR version 1.5 (FINNv1.5) (Wiedinmyer et al., 2011), which classifies burnings of extra-tropical forest, tropical forest (including peatland), savanna, and grassland. It is used in this study to provide daily, $36 \mathrm{~km}$ resolution $\mathrm{PM}_{2.5}$ emissions. The second emission inventory is the Global Fire Emission Database version 4.1 with small fires included (GFEDv4.1s) (van der Werf et al., 2010; Randerson et al., 2012; Giglio et al., 2013). GFEDv4.1s provides $\mathrm{PM}_{2.5}$ emissions with the same spatiotemporal resolution as FINNv1.5.

Our simulations cover a time period slightly longer than a decade from 2003 to 2014 based on available biomass burning emission estimates. The simulation of each year started on 1 November of the previous year and lasted for 14 months. The first two months were used for spin-up.

Three sets of decade-long simulations have been conducted. The first simulation used NCEP-FNL reanalysis data and the FINNv1.5 fire emission inventory. This simulation is hereafter referred to as FNL_FINN and is discussed as the base simulation. In order to examine the influence of different meteorological inputs on the fire aerosol life cycle, the second simulation was conducted using the same FINNv1.5 fire emission inventory as in FNL_FINN but a different reanalysis dataset, the ERA-Interim, and is referred to as ERA_FINN. In addition, to investigate the variability of fire aerosol concentration brought by the use of different estimates of fire emissions, the third simulation, FNL_GFED, was driven by the same NCEP-FNL meteorological input as in FNL_FINN but with a different fire emission inventory, the GFEDv4.1s.

A plume rise algorithm for fire emissions was implemented in WRF-Chem by Grell et al. (2011) to estimate fire injection height. This algorithm, however, often derives an injection height for tropical peat fire that is too high compared to the estimated value based on remote sensing retrievals (Tosca et al., 2011). Therefore, we have limited the plume injection height of peat fire by a ceiling of $700 \mathrm{~m}$ above the ground in this study, based on Tosca et al. (2011). The vertical distribution of emitted aerosols is calculated using the plume model. This modification has clearly improved the modeled surface $\mathrm{PM}_{2.5}$ concentration when compared to observations in Singapore.

In order to distinguish the spatiotemporal coverage and influence of biomass burning aerosols from different regions in Southeast Asia and nearby northern Australia, we have created five tracers to represent fire aerosols respectively from mainland Southeast Asia (s1), Sumatra and the Java islands (s2), Borneo (s3), the rest of the Maritime Continent (s4), and northern Australia (s5), as illustrated in Fig. 1. Based on this design, we are able to identify fire $\mathrm{PM}_{2.5}$ concentration from different regions and estimate the contribution to the total fire $\mathrm{PM}_{2.5}$ in a receptor city.

Generally speaking, the major fire season in mainland Southeast Asia (s1) is from February to April, and in the other four regions (s2-s5) it is from August to October. There is a strong anti-correlation between the seasonal variation of fire emissions and that of rainfall in all fire regions, as shown in Fig. 2. Because mainland Southeast Asia (s1) and northern Australia (s5) are on the edge of the seasonal migration of the ITCZ, the correlation in these two regions is even more pronounced. On the other hand, Sumatra (s2), Borneo (s3), and the rest of the Maritime Continent (s4) do not have clearly 
identifiable dry seasons and this contributes to the weaker correlation (Fig. 2b-d). Besides that, underground peatland burning may not be immediately extinguished by precipitation.

\subsection{Observational data and model derivation of visibility}

The definition of "visibility" is the farthest distance at which one can see a large, black object against a bright background at the horizon (Seinfeld and Pandis, 2006). There are several factors determining visibility, but here we mainly consider the absorption and scattering of light by gases and aerosol particles, excluding foggy or misty days. In this study, the modeled visibility is calculated by using the Koschmieder equation:

$\mathrm{VIS}=3.912 / b_{\mathrm{ext}}$,

where VIS is visibility with a unit in meters and $b_{\text {ext }}$ is the extinction coefficient. Excluding fog, visibility degradation is most readily observed from the impact of particulate pollution. Based on Eq. (1), a maximum visibility under absolutely dry and pollution-free air is about $296 \mathrm{~km}$ owing to Rayleigh scattering, while a visibility in the order of $10 \mathrm{~km}$ is considered indicative of moderate to heavy air pollution by particulate matter (Visscher, 2013). Abnormal and persistent low-visibility situations are also referred to as "haze" events. Air pollution sources such as fossil fuel burning can cause low visibility and haze events to occur. Similarly, fire aerosols, alone or mixed with other particulate pollutants, can degrade visibility by increasing $b_{\text {ext }}$ and lead to occurrences of haze events too.

The observational data of visibility from the Global Surface Summary of the Day (GSOD) (Smith et al., 2011) are used in our study to identify days under particulate pollution, i.e., haze events. The GSOD is derived from the Integrated Surface Hourly (ISH) dataset and archived at the National Climatic Data Center (NCDC). The daily visibility in the dataset is available from 1973 to the present.

The observed visibility is also used to evaluate the modeled visibility and thus $\mathrm{PM}_{2.5}$ concentration. The modeled visibility is derived based on the extinction coefficient of the fire aerosols as a function of particle size, by assuming a log-normal size distribution of accumulation mode with a standard deviation $\sigma=2$ (Kim et al., 2008). Note that all these calculations are done for the wavelength of $550 \mathrm{~nm}$ unless otherwise indicated. As fire plumes contain both sulfur compounds and carbonaceous aerosols, we assume the fire aerosols are aged internal mixtures with black carbon as the core and sulfate as the shell (Kim et al., 2008). To make the calculated visibility of the fire aerosols better match the reality, we have also considered hydroscopic growth of the sulfate fraction of these mixed particles in the calculation based on the modeled relative humidity (RH). Based on Kiehl et al. (2000), the hydroscopic growth factor (rhf) is given by
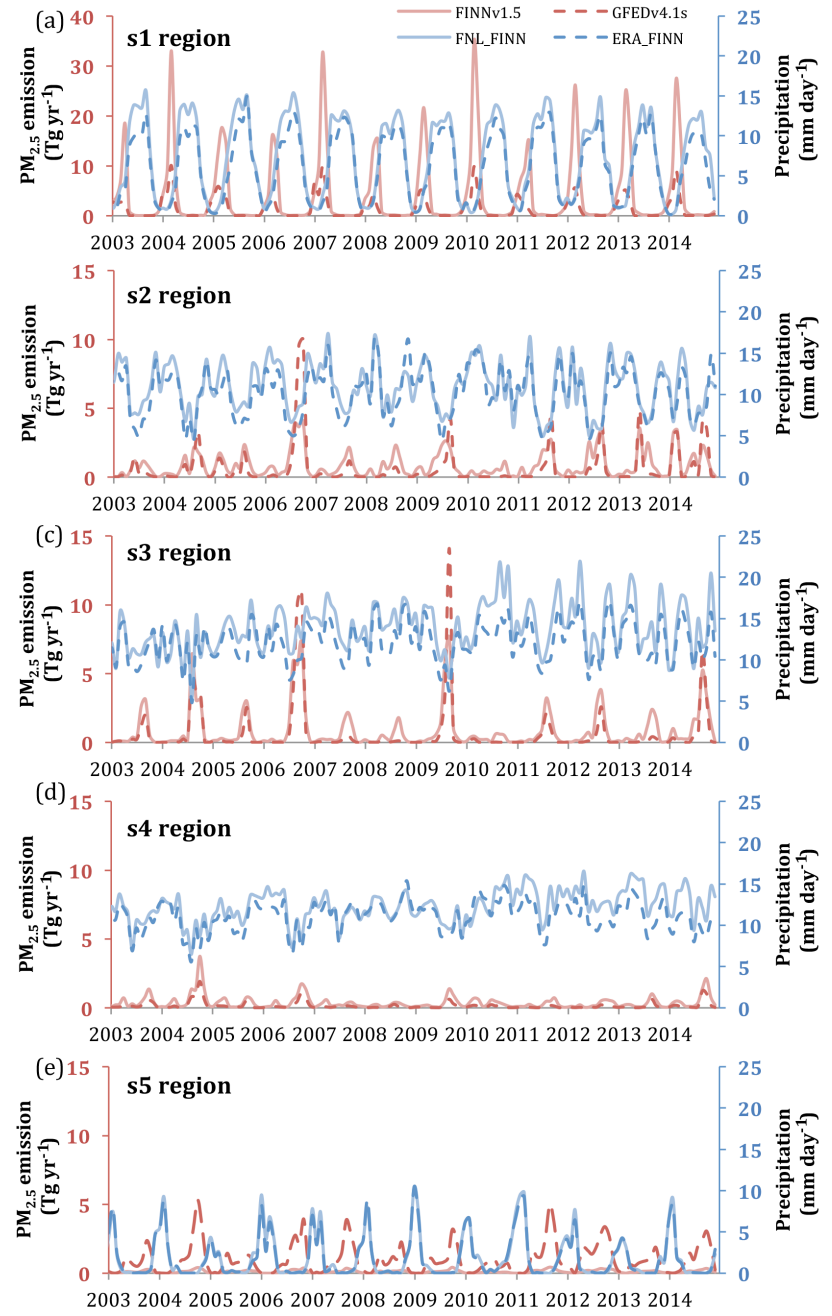

Figure 2. Time series of monthly $\mathrm{PM}_{2.5}$ emission $\left(\mathrm{Tg} \mathrm{yr}^{-1}\right)$ in FINNv1.5 (pink solid lines) and GFEDv4.1s (red dashed lines). Also shown are precipitation rates $\left(\mathrm{mmday}^{-1}\right)$ simulated in FNL_FINN (light blue solid lines) and ERA_FINN (blue dashed lines) during 2003-2014 in (a) mainland Southeast Asia (s1), (b) Sumatra and the Java islands (s2), (c) Borneo (s3), (d) the rest of the Maritime Continent (s4), and (e) northern Australia (s5).

the following:

$\mathrm{rhf}=1.0+\exp \left(a_{1}+\frac{a_{2}}{\mathrm{RH}+a_{3}}+\frac{a_{4}}{\mathrm{RH}+a_{5}}\right)$,

where $a_{1}$ to $a_{5}$ are fitting coefficients given by 0.5532 , $-0.1034,-1.05,-1.957$, and 0.3406 , respectively. The radius increase of wet particle $\left(r_{\text {wet }}\right)$ due to hydroscopic growth will be as follows:

$r_{\text {wet }}=\left(r_{\text {dry }}\right)^{\text {rhf }}$,

where $r_{\text {dry }}$ is the radius of a dry particle in micron.

As mentioned above, a visibility of $10 \mathrm{~km}$ is considered an indicator of moderate to heavy particulate pollution. Hence 
an observed visibility of $10 \mathrm{~km}$ is used as the threshold for defining the "low-visibility day" (VLD) in our study. We firstly derived the observed low-visibility days in every year for a given city using the GSOD visibility data. Then, we derived the modeled low-visibility days following the same procedure but using modeled visibility data that were only influenced by fire aerosols. Both the observed and modeled visibilities were then used to define the fraction of low-visibility days that can be explained by fire aerosols alone. It is assumed that whenever fire aerosol alone could cause a lowvisibility day to occur, such a day would be attributed to fire aerosol-caused LVD, regardless of whether other coexisting pollutants would have a sufficient intensity to cause low visibility or not. In addition to the LVD, we have also used a daily visibility of $7 \mathrm{~km}$ as the criterion to define the observed "very low visibility day" (VLVD). Such heavy haze events in the region are generally caused by severe fire aerosol pollution, thus we use their occurrence specifically to evaluate the model performance.

\subsection{The "haze exposure day" (HED)}

We have derived a metric, the haze exposure day (HED), to measure the exposure of the whole of Southeast Asia, represented by 50 cities of the Association of Southeast Asian Nations (ASEAN), to low-visibility events. HED can be defined in a population-weighted format for the analyzed 50 cities, indicating the relative exposure of the populations in these cities to the low-visibility events caused by particulate pollution.

$\mathrm{HED}_{\mathrm{pw}}=\sum_{i=1}^{N} C_{\mathrm{pw}}(i)$,

where

$C_{\mathrm{pw}}(i)=\operatorname{pop}(i) \cdot C(i) / \sum_{i=1}^{N} \operatorname{pop}(i)$

which is the population-weighted fraction of the total HEDs, where $N$ equals to the total number of cities (50), $i$ is the index for the 50 analyzed cities, $\operatorname{pop}(i)$ is the population for a given city (Table S1 in the Supplement), and $C(i)$ represents the annual LVDs for that city calculated from the GSOD dataset. Note that we assume that the population of each city stays constant throughout the analyzed period. Another assumption of $\mathrm{HED}_{\mathrm{pw}}$ is that everyone in a given city would be equally exposed to the particulate pollution.

In addition, HED can be also defined in an arithmetic mean format, assuming each city weights equally regardless of its population. Its value hence emphasizes the relative exposure of each area within the analyzed region:

$\mathrm{HED}_{\mathrm{ar}}=\sum_{i=1}^{N} C(i) / N$
Both $\mathrm{HED}_{\mathrm{pw}}$ and $\mathrm{HED}_{\mathrm{ar}}$ can be also calculated using firecaused LVDs to define the absolute and relative contributions of fire aerosols to the total low-visibility events in the region. We will label the fire-caused HED as fHED $\mathrm{pw}_{\text {and }}$ aHED $\mathrm{ar}_{\mathrm{ar}}$.

\section{Assessment of the impact of fire aerosols on the visibility in Southeast Asia}

\subsection{Impact of fire aerosols on the visibility in four selected cities}

We first focus our analysis on four selected cities in the region, Bangkok (Thailand), Kuala Lumpur (Malaysia), Singapore (Singapore), and Kuching (Malaysia), all located close to the major fire sites ranging from the mainland to the islands of Southeast Asia. Specifically, Bangkok is a smoke receptor city for the fire events in mainland of Southeast Asia (s1) while Kuala Lumpur and Singapore are two cities frequently under the influence of Sumatran (s2) as well as Bornean fires (s3). Kuching is in the coastal area of Borneo and directly affected by Bornean fire events (s3).

The surface observational data of $\mathrm{PM}_{2.5}$ concentration among these four cities are only available in Singapore since 2013 from the National Environment Agency (NEA) of Singapore. We thus first use these data along with visibility data to evaluate the model's performance for firecaused haze events reported in Singapore during 2013-2014 (Fig. 3). Note that the observed $\mathrm{PM}_{2.5}$ level reflects the influences of both fire and non-fire aerosols, whereas the modeled $\mathrm{PM}_{2.5}$ only includes the impact of fire aerosols. We find that the model still clearly predicted high $\mathrm{PM}_{2.5}$ concentrations during most of the observed haze events, especially in June 2013, and in the spring and fall seasons of 2014, though with underestimations in particle concentration of up to $30-50 \%$, likely due to the model's exclusion of non-fire aerosols, coarse model resolution, overestimated rainfall, or errors in the emission inventory. Figure 4 shows observed visibility versus modeled visibility in FNL_FINN during the fire events shown in Fig. 3. Note that all these events have an observed visibility lower than or equal to $10 \mathrm{~km}$, or can be identified as LVDs. In capturing these fire-caused haze events, the model only missed about $22 \%$ of them, reporting a visibility larger than $10 \mathrm{~km}$ in 40 out of 185 observed LVDs as marked with purple color in Fig. 4. When observed visibility is between 7 and $10 \mathrm{~km}$, model results appear to align with observations rather well. For cases with visibility lower than $7 \mathrm{~km}$, the model captured all the events (by reporting a visibility lower than $10 \mathrm{~km}$, or LVD) although often overestimated the visibility range. These results imply that the VLVDs only count a very small fraction in LVDs and thus are episodic events. It is very likely that the size of concentrated fire plumes in VLVDs might be constantly smaller than the $36 \mathrm{~km}$ model resolution; therefore, the model results could 


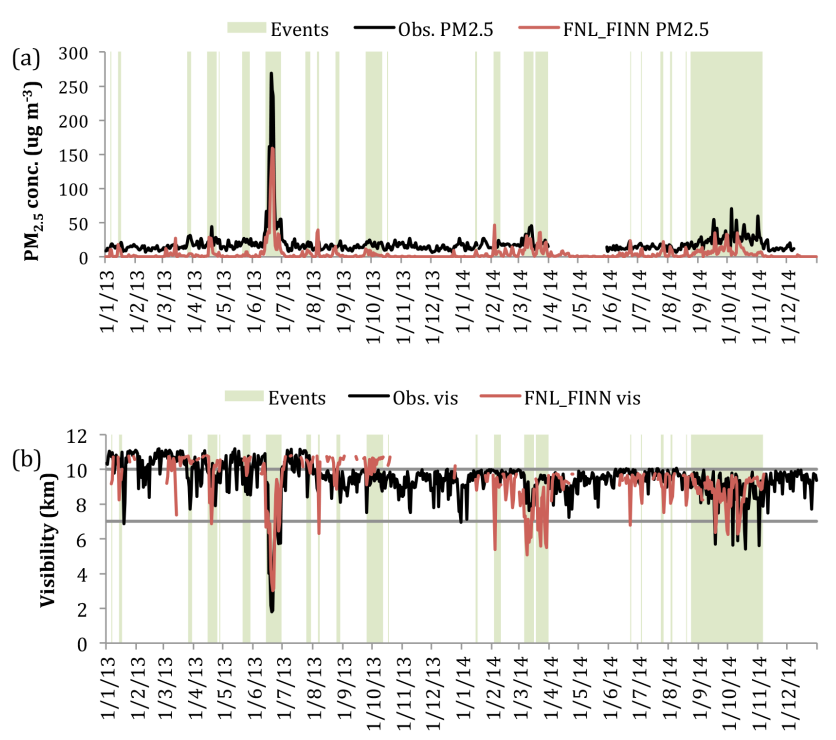

Figure 3. (a) Time series of daily surface $\mathrm{PM}_{2.5}$ from the groundbased observations (black line) and FNL_FINN-simulated results (red line) in Singapore during 2013-2014. (b) Same as (a) but daily visibility from GSOD observations (black line) and calculated results from FNL_FINN (red line). Highlighted green areas are known haze events caused by fire aerosols, which are reported by news or manually selected based on observed $\mathrm{PM}_{2.5}$. Two gray lines mark the visibility of 7 and $10 \mathrm{~km}$.

not reach the peak values of $\mathrm{PM}_{2.5}$ concentrations of these plumes.

Furthermore, the LVDs in the four selected near-fire-site cities during the fire seasons from 2003 to 2014 have been identified using the daily GSOD visibility database and then compared with modeled results (Fig. 5). It is difficult to identify all the fire-caused haze events beyond Singapore even in recent years. However, in Southeast Asia, severe haze events equivalent to the VLVDs in visibility degradation are known to be largely caused by fire aerosol pollution. Therefore, we used the observed VLVDs in the four selected cities to evaluate the performance of the model. We find that the modeled result displays a good performance in capturing VLVDs despite an overestimate in visibility range during certain events compared with the observation. The model in general only missed about $10 \%$ or fewer VLVDs observed in the past decade (Table 2; Fig. 5). In addition, the model has reasonably captured the observed LVDs despite certain biases (Fig. 5), likely due to the fact that fire aerosol might not be the only reason for the degradation of visibility during many LVDs.

We find that the annual mean LVD in Bangkok has increased from $47 \%$ (172 days) in the first 5 year period of the simulation duration (2003-2007) to $74 \%$ (272 days) in the last 5 year period (2010-2014). The LVDs caused by fire aerosols have increased as well (Fig. 6a). Overall, fire aerosols are responsible for more than one third of these

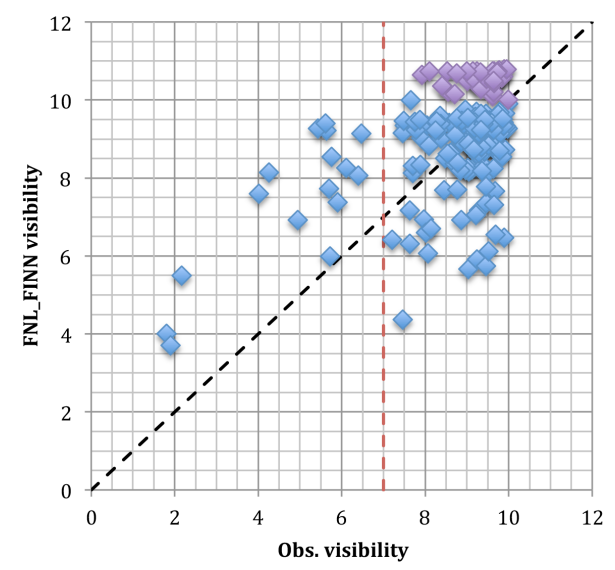

Figure 4. A scatterplot of observed visibility and FNL_FINN visibility during known fire events as labeled in Fig. 3b. The black dashed line refers to the $1: 1$ line and the red line is the threshold of VLVD $(7 \mathrm{~km})$. Purple points remark the known low-visibility events that the model failed to produce a visibility at least qualified for LVD.

LVDs (i.e., $39 \%$ in average; Table 2). The largest source of fire aerosols affecting Bangkok is the burning of agricultural waste and other biomass in s1 during the dry season of spring (Fig. 7a; Table 3). During the fire season, abundant fire aerosols degrade visibility and even cause VLVDs to occur, mainly from December to April (Fig. 6e). Based on our model results, $87 \%$ of VLVDs can be identified as caused by fires.

In Kuala Lumpur, the percentage of LVDs has also gradually increased since 2006 to reach a peak in 2011 and again in 2014 (Fig. 6b). During 2005-2010 the frequency of total LVDs have increased 10-15\% each year, mainly attributing to the pollution sources other than fires. However, firecaused LVDs become more evident after 2009. Seasonally, there are two peaks of fire aerosol influence, one in FebruaryMarch and another in August (Fig. 6f), corresponding to the trans-boundary transport of fire aerosols from mainland Southeast Asia (s1) in the winter monsoon season and from Sumatra (s2) in the summer monsoon season, respectively (Fig. 7b). Three quarters of VLVDs occurred in the summer monsoon season due to Sumatra fires. Note that in November and December the percentage of LVDs is over $50 \%$ and dominated by pollutants other than fire aerosols. These non-fire aerosols presumably come from either local sources or the areas further inland riding on the winter monsoon circulation. Overall, fire pollution is responsible for $36 \%$, a substantial fraction of total low-visibility events in Kuala Lumpur during 2003-2014 (Table 2).

The percentage of LVDs in Singapore has been rapidly increasing since 2012 (Fig. 6c). During the simulation period, this increase appears to be mostly from anthropogenic pollution other than fires, especially in 2012 and 2013. In monthly variation, similarly to Kuala Lumpur, two peaks 
(a)
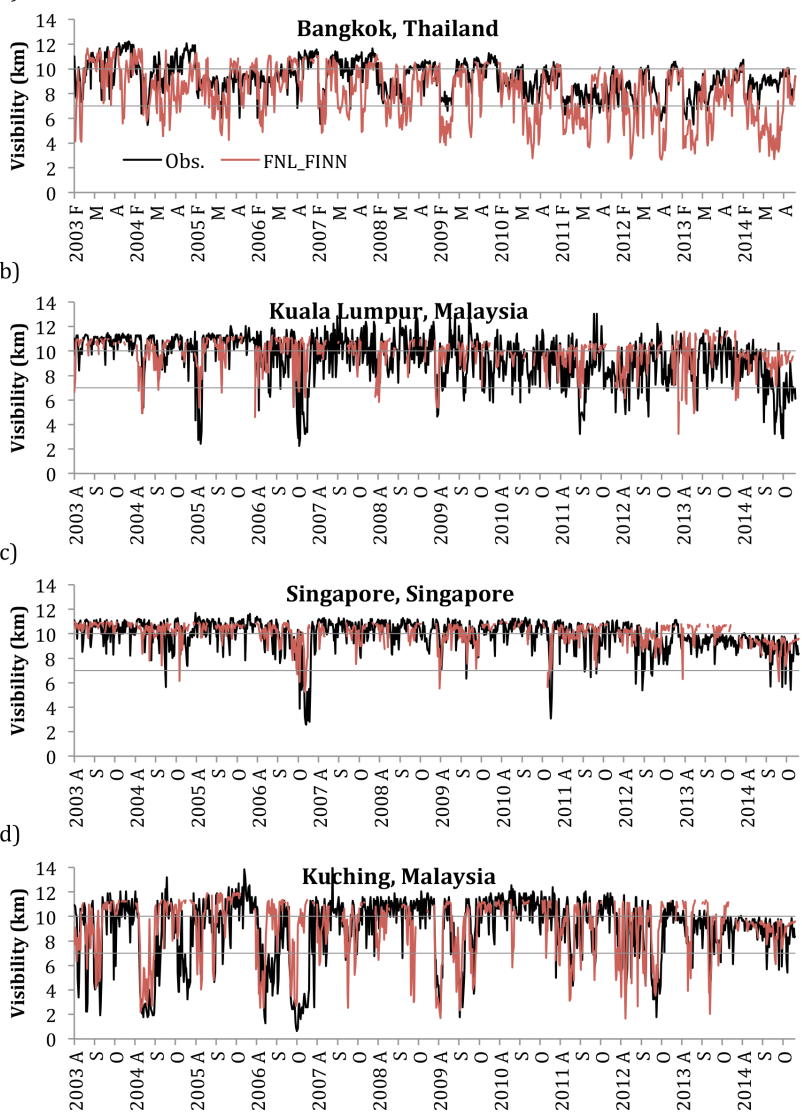

Figure 5. Comparison of daily visibility between GSOD observation (black lines) and FNL_FINN-modeled results (red lines) in (a) Bangkok, (b) Kuala Lumpur, (c) Singapore, and (d) Kuching during the fire seasons from 2003 to 2014 . Two grey lines mark the visibility of 7 and $10 \mathrm{~km}$, respectively. $\mathrm{F}, \mathrm{M}$, and $\mathrm{A}$ in the $x$ axis of (a) indicates February, March, and April, respectively. A, S, and $\mathrm{O}$ in the $x$ axis of (b)-(d) are August, September, and October, respectively.

of fire aerosol influence appear in February-March and in September-October, respectively (Fig. 6g). In February and March, the trans-boundary transport of fire aerosols come from mainland Southeast Asia (s1), while in the summer monsoon season fire aerosols come from both Sumatra (s2) and Borneo (s3) (Fig. 7c). Except for the severe haze events in June 2013, VLVDs basically occur in September and October (i.e., $92 \%$ ) due to both Sumatra and Borneo fires. In general, up to $34 \%$ of LVDs in Singapore are caused by fire aerosols based on the FNL_FINN simulation and the rest by local and long-range transported pollutants (Table 2). Nevertheless, fire aerosol is still the major reason for the episodic severe haze conditions.

Because of its geographic location, Kuching is affected heavily by local fire events during the fire season (Fig. 7d). Fire aerosols can often degrade the visibility to below $7 \mathrm{~km}$, even reaching $2 \mathrm{~km}$ (Fig. 5d). The LVDs mainly occur in Au-
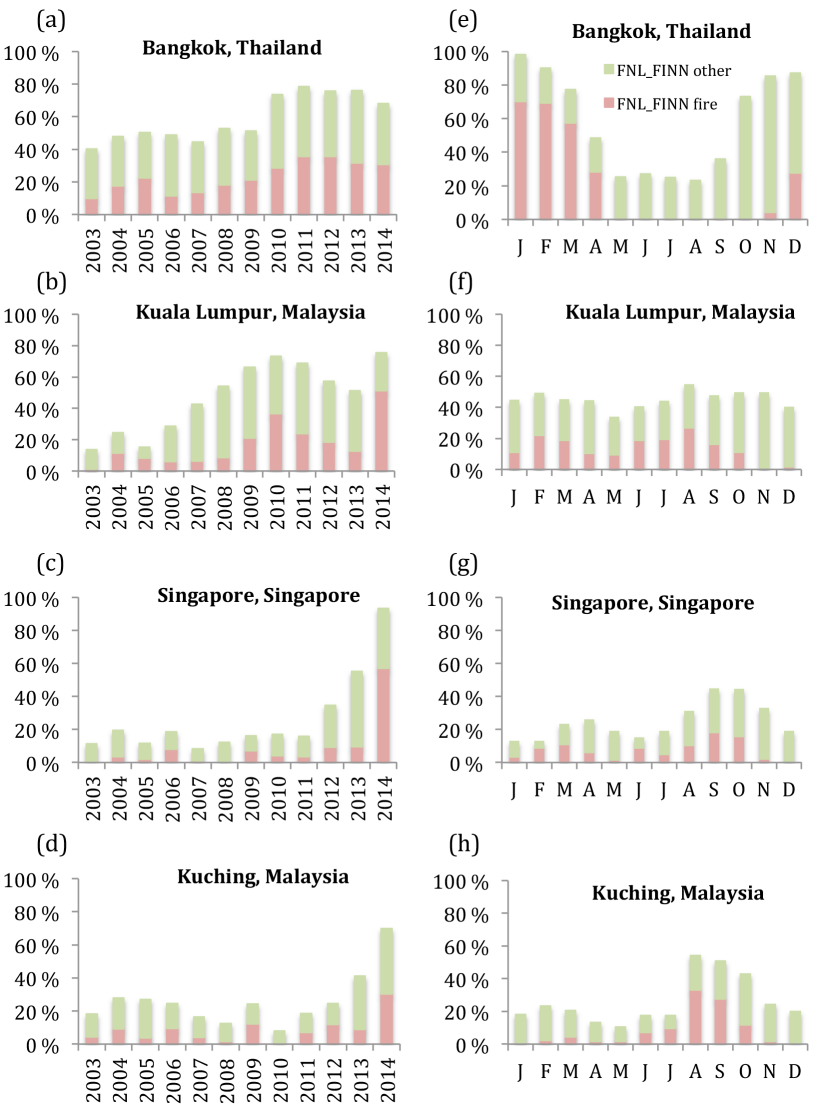

Figure 6. (a)-(d) The percentage of LVDs per year derived using from GSOD visibility observations in Bangkok, Kuala Lumpur, Singapore, and Kuching, respectively. (e)-(h) The percentage of LVDs averaged over 2003-2014, derived using GSOD visibility observations in Bangkok, Kuala Lumpur, Singapore, and Kuching, respectively. Each bar presents the observed LVDs in each year or month. Red color shows the partition of fire-caused LVDs (captured by model) while green color presents other LVDs (observed - modeled; i.e., those not captured by model).

gust and September during the fire season (Fig. 6d and h). The frequency of LVDs in Kuching is similar to Singapore; however, $25 \%$ of those LVDs are considered to be VLVDs in Kuching while in comparison only $4 \%$ are in Singapore (Table 2).

\subsection{Impact of fire aerosols on the visibility over the whole of Southeast Asia}

Air quality degradation caused by fires apparently occurs in regions beyond the above-analyzed four cities. To examine such degradation over the whole of Southeast Asia, we have extended our analysis to cover 50 cities of the ASEAN. The impact of particulate pollution on the whole of Southeast Asia is measured by the HED as defined in Sect. 2.3. The top 4 among the 50 cities that made the largest contributions to the $\mathrm{HED}_{\mathrm{pw}}$ are Jakarta, Bangkok, Hanoi, and Yan- 
(a)

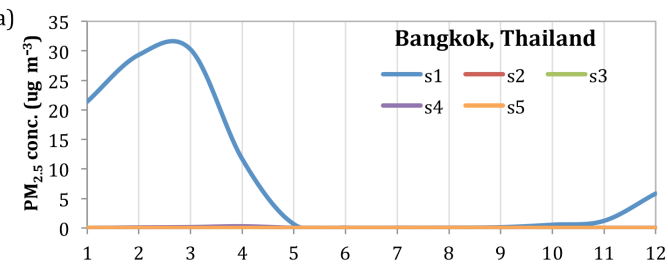

(b)

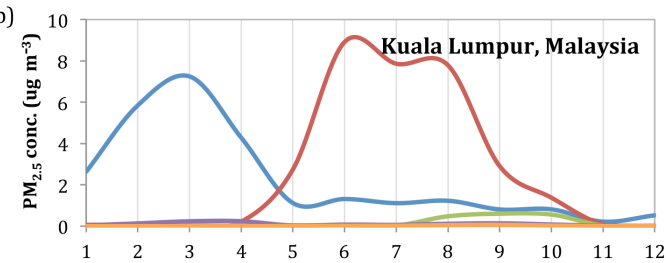

(c)

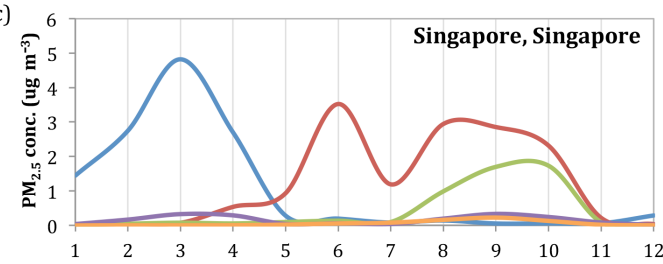

(d)

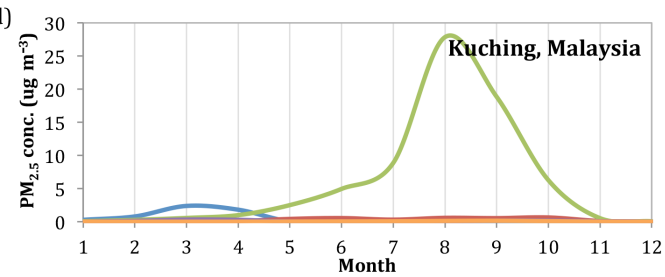

Figure 7. The mean fire $\mathrm{PM}_{2.5}$ concentrations within the $\mathrm{PBL}$ attributed to different emission regions (s1-s5) in (a) Bangkok, (b) Kuala Lumpur, (c) Singapore, and (d) Kuching, all derived from FNL_FINN simulation and averaged over the period 2003-2014.

gon (Fig. 8a), with a population ranking of 1, 2, 4, and 5, respectively (Table $\mathrm{S} 1$ ).

We find that both $\mathrm{HED}_{\mathrm{pw}}$ and $\mathrm{HED}_{\mathrm{ar}}$ have increased rather steadily over the past decade (Fig. 8b), demonstrating that the exposure to haze events, either weighted by population or not, has become worse in the region. Generally speaking, the fire aerosols are responsible for up to $40-60 \%$ of the total exposure to low visibility across the region. In both measures, the increase of fire-caused HED (2.64 and 3.37 days per year for population-weighted and arithmetic mean, respectively) is similar to that of overall HED (2.61 and 3.59 days per year for population-weighted and arithmetic mean, respectively) (Fig. 8b), suggesting that fire aerosols have taken the major role in degrading air quality in Southeast Asia compared to non-fire particulate pollution. The result that $\mathrm{HED}_{\mathrm{pw}}$ is higher than $\mathrm{HED}_{\mathrm{ar}}$ in most of the years indicates that the particulate pollution is on average worse over more populous cities than the others. Interestingly, the discrepancy between these two variables, however, has become smaller in recent years and even reversed in 2014, implying an increase of haze occurrence across cities with different populations in the re- (a)
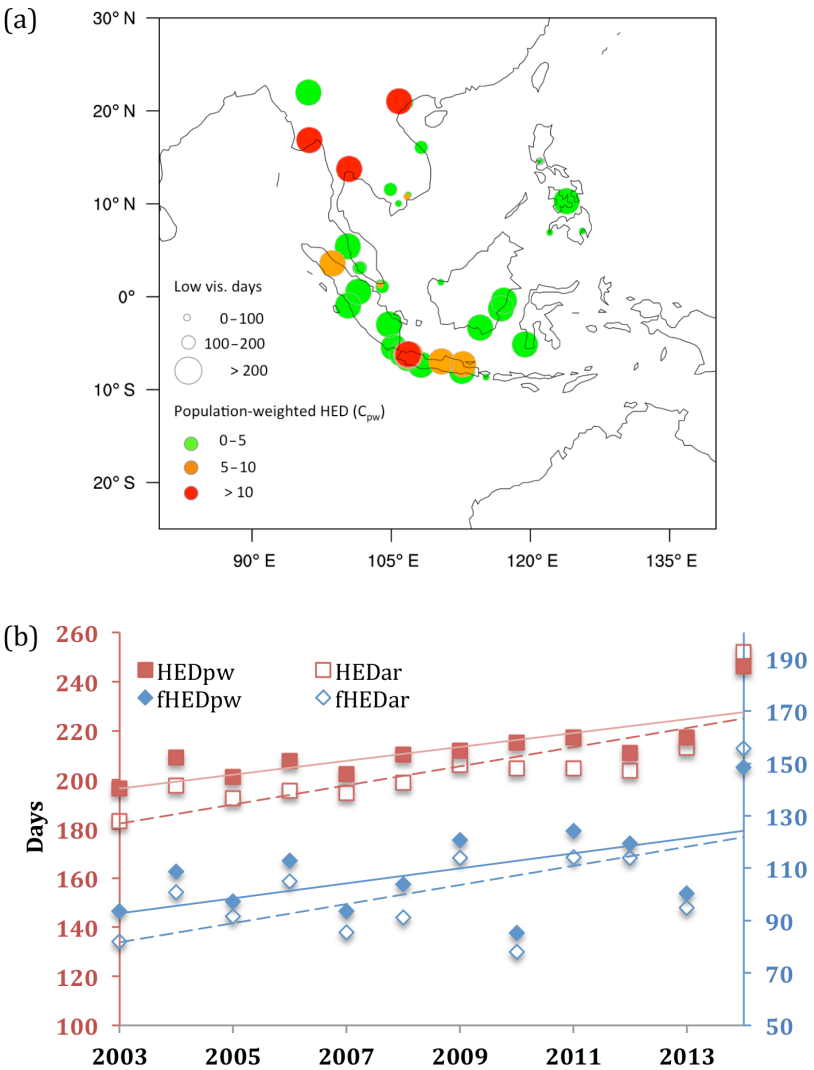

Figure 8. (a) The mean low-visibility days (circles) per year from 2003 to 2014 in 50 ASEAN cities. The size of the circles indicates the number of days. The colors refer to populationweighted fraction in the total haze exposure days (HEDs). (b) Annual population-weighted $\mathrm{HED}\left(\mathrm{HED}_{\mathrm{pw}}\right)$ and arithmetic mean HED (HED ${ }_{a r}$ ). Fire-caused HED are labeled as fHED $_{\mathrm{pw}}$ and $\mathrm{fHED}_{\mathrm{ar}}$. Units are in days. Note that the $y$ axes are in different scales.

gion. The reason behind this could be a wider spread of fire events in the region, causing acute haze events in cities even with relatively low populations. Regarding the increase of fire-caused HED, because biomass burning, especially peatland burning, usually occurs in the rural areas, higher fire emissions would extend low-visibility conditions to a larger area regardless of its population. On the other hand, due to industrialization, urbanization, and other factors such as population growth, air pollution has become worse across the region so even cities with lower populations now increasingly suffer from low visibility from fossil fuel burning and other sources of particulate pollution (IEA, 2015). Therefore, the mitigation of air quality degradation needs to consider both fire and non-fire sources. 
Table 2. Annual mean low-visibility days (LVDs; observed visibility $\leq 10 \mathrm{~km}$ ) and very low-visibility days (VLVDs; observed visibility $\leq 7 \mathrm{~km}$ ) per year in Bangkok, Kuala Lumpur, Singapore, and Kuching during 2003-2014 are presented in the second column. Parentheses show the percentage of year. The third column shows the percentages, along with standard deviations, of low-visibility days explained by fire aerosols alone (i.e., the LVDs captured by the model). The fourth column is the same as the third column but for non-fire (other) pollutions, which is calculated as $100 \%$ - fire pollution contribution (i.e., the percentage of LVDs not captured by the model).

\begin{tabular}{|c|c|c|c|}
\hline FNL_FINN & $\begin{array}{r}\text { LVD per year } \\
\text { (days) }\end{array}$ & $\begin{array}{l}\text { Fire pollution } \\
\text { contribution }(\%)\end{array}$ & $\begin{array}{l}\text { Other pollution } \\
\text { contribution }(\%)\end{array}$ \\
\hline Bangkok, Thailand & $215 \pm 50(59 \pm 14 \%)$ & $39 \pm 8$ & $61 \pm 8$ \\
\hline Kuala Lumpur, Malaysia & $174 \pm 78(48 \pm 21 \%)$ & $36 \pm 17$ & $64 \pm 17$ \\
\hline Singapore, Singapore & $96 \pm 87(26 \pm 24 \%)$ & $34 \pm 17$ & $66 \pm 17$ \\
\hline Kuching, Malaysia & $95 \pm 57(26 \pm 17 \%)$ & $33 \pm 15$ & $67 \pm 15$ \\
\hline FNL_FINN & $\begin{array}{r}\text { VLVD per year } \\
\text { (days) }\end{array}$ & $\begin{array}{l}\text { Fire pollution } \\
\text { contribution }(\%)\end{array}$ & $\begin{array}{l}\text { Other pollution } \\
\text { contribution }(\%)\end{array}$ \\
\hline Bangkok, Thailand & $15 \pm 8(4 \pm 2 \%)$ & $87 \pm 20$ & $13 \pm 20$ \\
\hline Kuala Lumpur, Malaysia & $19 \pm 18(5 \pm 5 \%)$ & $85 \pm 17$ & $15 \pm 17$ \\
\hline Singapore, Singapore & $4 \pm 4(1 \pm 1 \%)$ & $91 \pm 33$ & $9 \pm 33$ \\
\hline Kuching, Malaysia & $22 \pm 18(6 \pm 5 \%)$ & $93 \pm 11$ & $7 \pm 11$ \\
\hline ERA_FINN & $\begin{array}{r}\text { LVD per year } \\
\text { (days) }\end{array}$ & $\begin{array}{r}\text { Fire pollution } \\
\text { contribution }(\%)\end{array}$ & $\begin{array}{l}\text { Other pollution } \\
\text { contribution }(\%)\end{array}$ \\
\hline Bangkok, Thailand & $215 \pm 50(59 \pm 14 \%)$ & $46 \pm 7$ & $54 \pm 7$ \\
\hline Kuala Lumpur, Malaysia & $174 \pm 78(48 \pm 21 \%)$ & $40 \pm 16$ & $60 \pm 16$ \\
\hline Singapore, Singapore & $96 \pm 87(26 \pm 24 \%)$ & $37 \pm 18$ & $63 \pm 18$ \\
\hline Kuching, Malaysia & $95 \pm 57(26 \pm 17 \%)$ & $45 \pm 17$ & $55 \pm 17$ \\
\hline ERA_FINN & $\begin{array}{r}\text { VLVD per year } \\
\text { (days) }\end{array}$ & $\begin{array}{r}\text { Fire pollution } \\
\text { contribution }(\%)\end{array}$ & $\begin{array}{l}\text { Other pollution } \\
\text { contribution }(\%)\end{array}$ \\
\hline Bangkok, Thailand & $15 \pm 8(4 \pm 2 \%)$ & $88 \pm 20$ & $12 \pm 20$ \\
\hline Kuala Lumpur, Malaysia & $19 \pm 18(5 \pm 5 \%)$ & $90 \pm 18$ & $10 \pm 18$ \\
\hline Singapore, Singapore & $4 \pm 4(1 \pm 1 \%)$ & $98 \pm 6$ & $2 \pm 6$ \\
\hline Kuching, Malaysia & $22 \pm 18(6 \pm 5 \%)$ & $94 \pm 11$ & $6 \pm 11$ \\
\hline FNL_GFED & $\begin{array}{r}\text { LVD per year } \\
\text { (days) }\end{array}$ & $\begin{array}{r}\text { Fire pollution } \\
\text { contribution }(\%)\end{array}$ & $\begin{array}{l}\text { Other pollution } \\
\text { contribution }(\%)\end{array}$ \\
\hline Bangkok, Thailand & $215 \pm 50(59 \pm 14 \%)$ & $36 \pm 8$ & $64 \pm 8$ \\
\hline Kuala Lumpur, Malaysia & $174 \pm 78(48 \pm 21 \%)$ & $28 \pm 17$ & $72 \pm 17$ \\
\hline Singapore, Singapore & $96 \pm 87(26 \pm 24 \%)$ & $29 \pm 21$ & $71 \pm 21$ \\
\hline Kuching, Malaysia & $95 \pm 57(26 \pm 17 \%)$ & $26 \pm 18$ & $74 \pm 18$ \\
\hline FNL_GFED & $\begin{array}{r}\text { VLVD per year } \\
\text { (days) }\end{array}$ & $\begin{array}{r}\text { Fire pollution } \\
\text { contribution }(\%)\end{array}$ & $\begin{array}{l}\text { Other pollution } \\
\text { contribution }(\%)\end{array}$ \\
\hline Bangkok, Thailand & $15 \pm 8(4 \pm 2 \%)$ & $90 \pm 19$ & $10 \pm 19$ \\
\hline Kuala Lumpur, Malaysia & $19 \pm 18(5 \pm 5 \%)$ & $83 \pm 28$ & $17 \pm 28$ \\
\hline Singapore, Singapore & $4 \pm 4(1 \pm 1 \%)$ & $89 \pm 37$ & $11 \pm 37$ \\
\hline Kuching, Malaysia & $22 \pm 18(6 \pm 5 \%)$ & $89 \pm 28$ & $11 \pm 28$ \\
\hline
\end{tabular}

\subsection{The influence of wind and precipitation on fire aerosol life cycle}

Seasonal migrations of the ITCZ and associated summer and winter monsoons dominate seasonal wind flows that drive fire aerosol transport. Additionally, as discussed previously, certain small-scale or short-term phenomena such as sea breezes, typhoons, and topography-forced circulations also play important roles in distributing fire aerosols. Nevertheless, we focus our discussion here on the former.

The period from February to April is the main fire season in mainland Southeast Asia (s1). In the FNL_FINN simulation, the seasonal mean concentration of $\mathrm{PM}_{2.5}$ within the PBL can exceed $20 \mu \mathrm{g} \mathrm{m}^{-3}$ in this region (note that the air quality standard suggested by World Health Origination is $10 \mu \mathrm{g} \mathrm{m}^{-3}$ for annual mean and $25 \mu \mathrm{g} \mathrm{m}^{-3}$ for $24 \mathrm{~h}$ mean). 
(a)
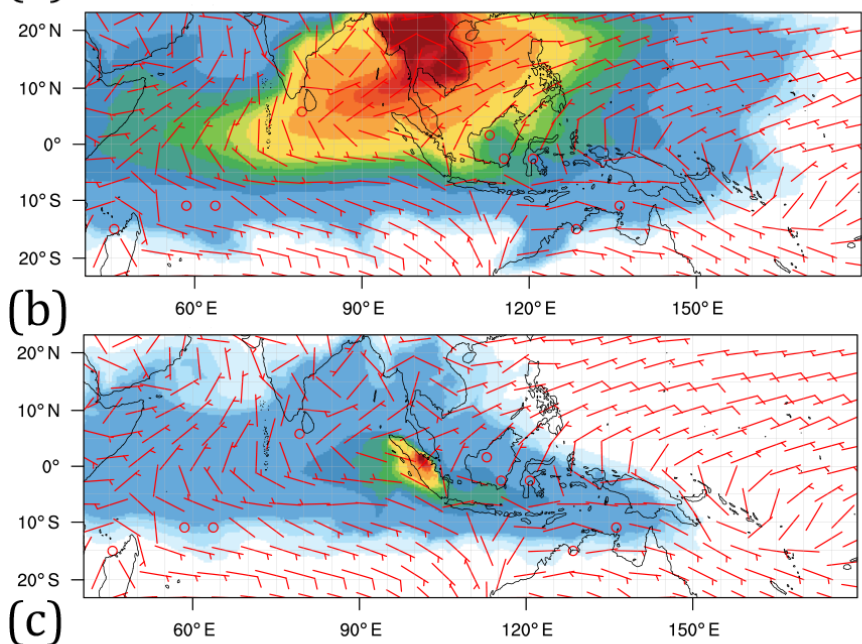

(c)

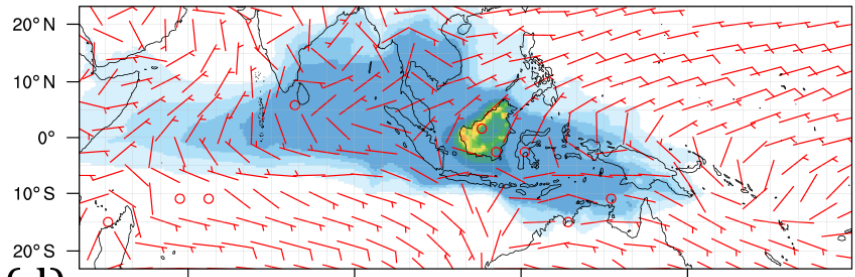

(d)

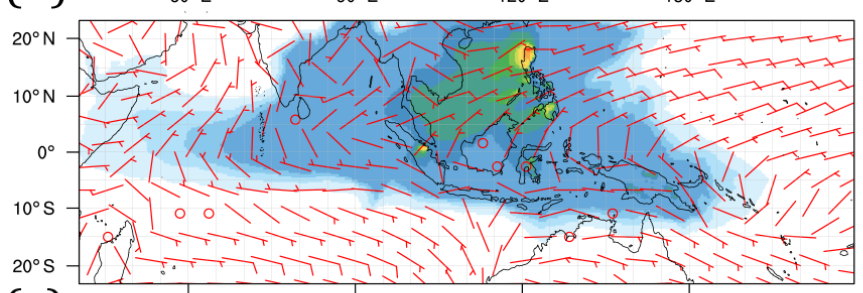

(e)

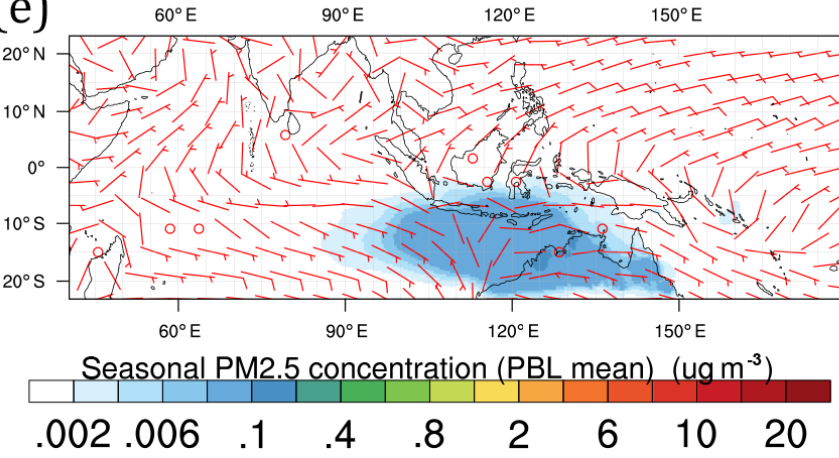

(f)
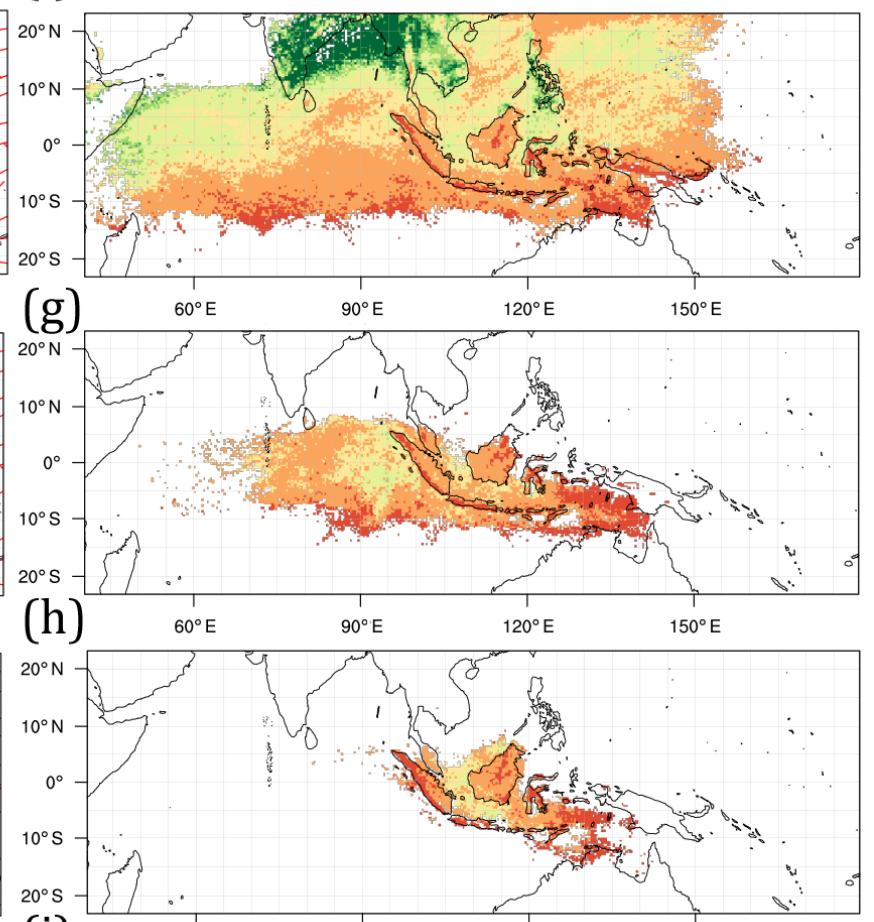

(i)

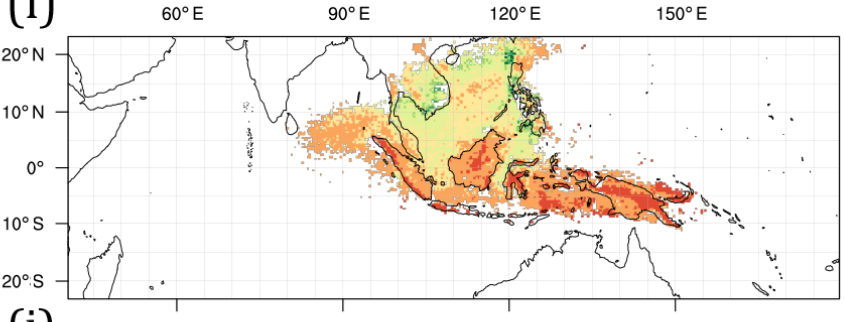

(j) $\quad 60^{\circ} \mathrm{E} \quad 90^{\circ}$

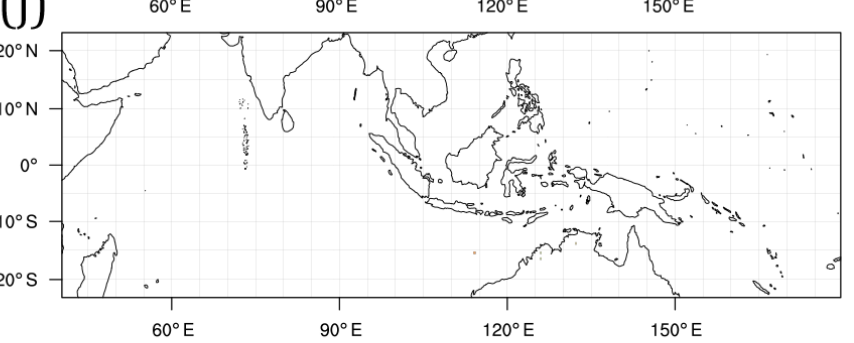

Seasonal mean scavenging time (below PBLH) (days)

Figure 9. Seasonal mean fire $\mathrm{PM}_{2.5}$ concentration $\left(\mu \mathrm{g} \mathrm{m}^{-3}\right)$ and wind within the PBL modeled in FNL_FINN during February to April, 2003-2014 for fire $\mathrm{PM}_{2.5}$ source region from (a) mainland Southeast Asia, (b) Sumatra and the Java islands, (c) Borneo, (d) the rest of the Maritime Continent, and (e) northern Australia. (f)-(j) Same as (a)-(e) but for seasonal mean wet scavenging time (days).

During this fire season, the most common wind direction is from northeast to southwest across the region (Fig. 9a). Fire aerosol plumes with concentrations higher than $0.1 \mu \mathrm{g} \mathrm{m}^{-3}$ can be transported westward as far as $7000 \mathrm{~km}$ from the burning sites (Fig. 9a). In contrast, February to April is not the typical burning season on the islands. Low fire emissions, in combination with a lack of long-range transport of fire aerosols from the mainland due to the seasonal circulation, result in a low $\mathrm{PM}_{2.5}$ level over these regions (Fig. 9b-d).

Wet scavenging is a major factor determining the lifetime and thus abundance of suspended fire aerosols in the air. The effect of wet scavenging of fire aerosols is reflected in the wet scavenging time calculated using the modeled results, which is a ratio of the aerosol mass concentration to 
the scavenging rate (a function of precipitation rate). Thus, short scavenging times often indicate high scavenging rates except for the sites with extremely low aerosol concentration. During February-April, at the ITCZ's furthest southern extent, the short scavenging time $<1$ day around $10^{\circ} \mathrm{S}$ shows a quick removal of fire aerosols by heavy precipitation, preventing the southward transport of aerosols (Fig. 9f). On the other hand, the long scavenging time ( $>5$ days) in the Western Pacific warm pool, South China Sea, Indochina peninsula, Bay of Bengal, and Arabian Sea leads to a long suspending time of aerosols transported to these regions. During the same season, over the islands of Sumatra and Borneo, the abundance of fire aerosols, either emitted locally or trans-boundary transported, are greatly limited by the high scavenging rate (short scavenging time) over these regions (Fig. 9g and h). The South China Sea has little precipitation during this time period; therefore, fire aerosols from the northern part of the Philippines can be transported to this region and stay longer than 5 days (Fig. 9i).

The months of August to October, when the ITCZ reaches its furthest northern extent, mark the major fire season of Sumatra, Borneo, and some other islands in the MC (Fig. S1b-d in the Supplement). Australian fires also mainly occur in this season (Fig. S1e). Mean wind flows are from southeast to northwest in the Southern Hemisphere, and turn to the northeast direction once past the Equator. Within the MC the seasonal variation of rainfall is small during this time, with heavy precipitation and thus short scavenging times ( $<3$ days) existing along the MJO path (Fig. S1f-i) (Wu and Hsu, 2009). The high scavenging rate in the regions close to the fire sites in the islands shortens the transport distance of fire aerosol plumes with $\mathrm{PM}_{2.5}$ concentration $>0.1 \mu \mathrm{g} \mathrm{m}^{-3}$ to less than $3000 \mathrm{~km}$ (Fig. S1b-d). Long scavenging times ( $>5$ days) exist in the Banda Sea and northern Australia due to the ITCZ location. Fire aerosols from Java (s2) (Fig. S1g), Papua New Guinea (s4) (Fig. S1i), and northern Australia (s5) (Fig. S1j) can thus be suspended in the air for a relatively long time over these regions.

The above-discussed seasonal features of precipitation and aerosol scavenging rate help us to better understand the variability of haze occurrence and also to identify the major source regions of fire aerosols influencing selected Southeast Asian cities (Fig. 7). For example, the geographic location of Bangkok, which is inside the s1 emission region, determines that nearly all the fire aerosols (99\%) are from sources within the region from December to April (Fig. 7a and Table 3). Fire aerosols from all the other burning sites stay at very low levels even during the burning seasons there due to circulation and precipitation scavenging. For Kuala Lumpur and Singapore, over $90 \%$ of the fire aerosols reaching both cities come from mainland Southeast Asia (s1) in JanuaryApril due to the dominant winter monsoon circulation. During May-October, however, the major sources of fire aerosols shift to Sumatra (s2) and Borneo (s3) aided by northward wind (Fig. S1b and c). The monthly variations of $\mathrm{PM}_{2.5}$ concentration in Kuala Lumpur and Singapore also have a largely similar pattern (Fig. 7b and c). The annual mean contribution of different emission regions in Kuala Lumpur are $43 \%$ from mainland Southeast Asia (s1), 50\% from Sumatra (s2), $4 \%$ from Borneo (s3), $3 \%$ from the rest of Maritime Continent (s4), and $0.3 \%$ from northern Australia (s5) in FINL_FINN (Table 3). Similarly to Kuala Lumpur, there are two peak seasons of the monthly low-visibility days contributed by fire aerosols in Singapore (Fig. 6g), well correlated with modeled high fire $\mathrm{PM}_{2.5}$ concentration (Fig. 7c). The low-visibility days in March and April mainly are caused by fire aerosols from mainland Southeast Asia (s1) under a southward wind pattern (Fig. 9a), and those in May to October are affected by Sumatra (s2) first in May to June, and then by both s2 and s3 (Borneo) during August to October due to north- or northwest-ward monsoonal circulation (Fig. S1b and c; also Table 3). Kuching, similarly to Bangkok, is strongly affected by local fire aerosols (s3) during the fire season (July-October). The annual mean contribution from Borneo (s3) is $85 \%$, with only $8 \%$ from mainland Southeast Asia (s1) and 5\% from Sumatra (s2) (Table 3).

\section{Influence of different meteorological datasets and emission inventories on modeled fire aerosol abundance}

\subsection{Different meteorological datasets}

Meteorological conditions, particularly wind fields and precipitation, could substantially influence the life cycle and transport path of fire aerosols during the fire seasons. First of all, we use these two variables to evaluate the model's performance in simulating meteorological features. The WRF simulation driven by NCEP-FNL reanalysis data, the FNL_FINN run, produced a monthly mean precipitation of $6.80 \pm 0.55 \mathrm{~mm} \mathrm{day}^{-1}$ over the modeled domain for the period from 2003 to 2014 , very close to the value of $6.30 \pm 0.43 \mathrm{~mm} \mathrm{day}^{-1}$ produced in another simulation driven by ERA-Interim, the ERA_FINN run. However, the average rainfall in both runs appears to be higher than the monthly mean of $4.71 \pm 0.37 \mathrm{~mm} \mathrm{day}^{-1}$ from the satelliteretrieved precipitation of the Tropical Rainfall Measuring Mission (TRMM) 3B43 (V7) dataset (Huffman et al., 2007). Based on the sensitivity tests for FDDA grid nudging, the wet bias in both experiments mainly comes from water vapor nudging. Figure S2a-c are the Hovmöller plots of daily TRMM, FNL_FINN, and ERA_FINN precipitation in 2006, respectively. Compared to the satellite-retrieved data, both FNL_FINN and ERA_FINN have produced more light rain events, and this appears to be the reason behind the model precipitation bias. Despite the model overestimate in average total precipitation, the temporal correlation of monthly rainfall between FNL_FINN and TRMM is 0.68 and the 
Table 3. Annual mean and standard deviation of modeled fire $\mathrm{PM}_{2.5}$ concentration $\left(\mu \mathrm{g} \mathrm{m}^{-3}\right)$ in Bangkok, Kuala Lumpur, Singapore, and

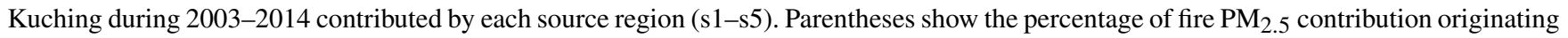
from each source region. Regions s1-s5 are defined in Fig. 1. FNL_FINN, ERA_FINN, and FNL_GFED are three model simulations described in Sect. 2.1.

\begin{tabular}{|c|c|c|c|c|c|}
\hline FNL_F & s1 & $\mathrm{s} 2$ & s3 & s4 & s5 \\
\hline Bangkok & $\begin{array}{r}8.4 \pm 2.3 \\
(99.2 \pm 0.5 \%)\end{array}$ & $\begin{array}{r}0.0 \pm 0.0 \\
(0.1 \pm 0.1 \%)\end{array}$ & $\begin{array}{r}0.0 \pm 0.0 \\
(0.1 \pm 0.1 \%)\end{array}$ & $\begin{array}{r}0.1 \pm 0.0 \\
(0.6 \pm 0.5 \%)\end{array}$ & $\begin{array}{r}0.0 \pm 0.0 \\
(0.0 \pm 0.0 \%)\end{array}$ \\
\hline Kuala Lumpur & $\begin{array}{r}2.3 \pm 1.2 \\
(43.3 \pm 14.8 \%)\end{array}$ & $\begin{array}{r}2.7 \pm 1.4 \\
(49.6 \pm 14.9 \%)\end{array}$ & $\begin{array}{r}0.2 \pm 0.2 \\
(3.3 \pm 3.4 \%)\end{array}$ & $\begin{array}{r}0.1 \pm 0.1 \\
(2.5 \pm 2.3 \%)\end{array}$ & $\begin{array}{r}0.0 \pm 0.0 \\
(0.3 \pm 0.2 \%)\end{array}$ \\
\hline Singapore & $\begin{array}{r}1.1 \pm 0.7 \\
(36.7 \pm 14.7 \%)\end{array}$ & $\begin{array}{r}1.2 \pm 0.8 \\
(40.7 \pm 15.9 \%)\end{array}$ & $\begin{array}{r}0.4 \pm 0.4 \\
(14.3 \pm 10.0 \%)\end{array}$ & $\begin{array}{r}0.2 \pm 0.1 \\
(6.1 \pm 3.8 \%)\end{array}$ & $\begin{array}{r}0.1 \pm 0.0 \\
(2.2 \pm 1.1 \%)\end{array}$ \\
\hline Kuching & $\begin{array}{r}0.5 \pm 0.4 \\
(7.8 \pm 6.5 \%)\end{array}$ & $\begin{array}{r}0.3 \pm 0.1 \\
(4.7 \pm 2.5 \%)\end{array}$ & $\begin{array}{r}6.0 \pm 3.2 \\
(84.6 \pm 9.7 \%)\end{array}$ & $\begin{array}{r}0.1 \pm 0.1 \\
(2.3 \pm 2.5 \%)\end{array}$ & $\begin{array}{r}0.0 \pm 0.0 \\
(0.6 \pm 0.3 \%)\end{array}$ \\
\hline ERA_l & s1 & $\mathrm{s} 2$ & s3 & s4 & s5 \\
\hline Bangkok & $\begin{array}{r}9.1 \pm 2.3 \\
(99.2 \pm 0.4 \%)\end{array}$ & $\begin{array}{r}0.0 \pm 0.0 \\
(0.1 \pm 0.1 \%)\end{array}$ & $\begin{array}{r}0.0 \pm 0.0 \\
(0.1 \pm 0.1 \%)\end{array}$ & $\begin{array}{r}0.1 \pm 0.0 \\
(0.6 \pm 0.4 \%)\end{array}$ & $\begin{array}{r}0.0 \pm 0.0 \\
(0.0 \pm 0.0 \%)\end{array}$ \\
\hline Kuala Lumpur & $\begin{array}{r}2.3 \pm 1.2 \\
(39.7 \pm 12.7 \%)\end{array}$ & $\begin{array}{r}3.2 \pm 1.4 \\
(53.7 \pm 12.3 \%)\end{array}$ & $\begin{array}{r}0.2 \pm 0.2 \\
(3.9 \pm 3.3 \%)\end{array}$ & $\begin{array}{r}0.1 \pm 0.0 \\
(2.3 \pm 1.8 \%)\end{array}$ & $\begin{array}{r}0.0 \pm 0.0 \\
(0.4 \pm 0.2 \%)\end{array}$ \\
\hline Singapore & $\begin{array}{r}1.1 \pm 0.6 \\
(34.2 \pm 13.5 \%)\end{array}$ & $\begin{array}{r}1.4 \pm 0.9 \\
(40.5 \pm 13.7 \%)\end{array}$ & $\begin{array}{r}0.6 \pm 0.6 \\
(17.2 \pm 11.8 \%)\end{array}$ & $\begin{array}{r}0.2 \pm 0.1 \\
(6.2 \pm 3.1 \%)\end{array}$ & $\begin{array}{r}0.1 \pm 0.0 \\
(1.9 \pm 0.9 \%)\end{array}$ \\
\hline Kuching & $\begin{array}{r}0.5 \pm 0.4 \\
(8.1 \pm 5.6 \%)\end{array}$ & $\begin{array}{r}0.4 \pm 0.2 \\
(6.1 \pm 3.9 \%)\end{array}$ & $\begin{array}{r}6.7 \pm 3.9 \\
(82.5 \pm 10.0 \%)\end{array}$ & $\begin{array}{r}0.1 \pm 0.1 \\
(2.7 \pm 3.0 \%)\end{array}$ & $\begin{array}{r}0.0 \pm 0.0 \\
(0.6 \pm 0.3 \%)\end{array}$ \\
\hline FNL_GFED & s1 & $\mathrm{s} 2$ & s3 & 84 & s5 \\
\hline Bangkok & $\begin{array}{r}4.8 \pm 1.3 \\
(99.6 \pm 0.2 \%)\end{array}$ & $\begin{array}{r}0.0 \pm 0.0 \\
(0.1 \pm 0.0 \%)\end{array}$ & $\begin{array}{r}0.0 \pm 0.0 \\
(0.1 \pm 0.1 \%)\end{array}$ & $\begin{array}{r}0.0 \pm 0.0 \\
(0.2 \pm 0.2 \%)\end{array}$ & $\begin{array}{r}0.0 \pm 0.0 \\
(0.1 \pm 0.0 \%)\end{array}$ \\
\hline Kuala Lumpur & $\begin{array}{r}1.3 \pm 0.6 \\
(38.6 \pm 20.8 \%)\end{array}$ & $\begin{array}{r}2.7 \pm 1.9 \\
(53.8 \pm 21.1 \%)\end{array}$ & $\begin{array}{r}0.1 \pm 0.2 \\
(2.8 \pm 3.5 \%)\end{array}$ & $\begin{array}{r}0.0 \pm 0.0 \\
(0.8 \pm 0.8 \%)\end{array}$ & $\begin{array}{r}0.1 \pm 0.1 \\
(3.9 \pm 3.4 \%)\end{array}$ \\
\hline Singapore & $\begin{array}{r}0.3 \pm 0.2 \\
(22.1 \pm 17.3 \%)\end{array}$ & $\begin{array}{r}1.5 \pm 1.8 \\
(40.2 \pm 23.6 \%)\end{array}$ & $\begin{array}{r}0.4 \pm 0.5 \\
(12.5 \pm 9.5 \%)\end{array}$ & $\begin{array}{r}0.1 \pm 0.0 \\
(2.9 \pm 2.4 \%)\end{array}$ & $\begin{array}{r}0.4 \pm 0.2 \\
(22.3 \pm 13.2 \%)\end{array}$ \\
\hline Kuching & $\begin{array}{r}0.1 \pm 0.1 \\
(7.2 \pm 6.8 \%)\end{array}$ & $\begin{array}{r}0.1 \pm 0.1 \\
(4.3 \pm 3.2 \%)\end{array}$ & $\begin{array}{r}3.2 \pm 3.2 \\
(75.2 \pm 12.9 \%)\end{array}$ & $\begin{array}{r}0.0 \pm 0.0 \\
(1.7 \pm 2.7 \%)\end{array}$ & $\begin{array}{r}0.3 \pm 0.2 \\
(11.6 \pm 6.7 \%)\end{array}$ \\
\hline
\end{tabular}

spatial correlation is 0.85 during 2003-2014 (Table 4). For ERA_FINN, the temporal correlation with TRMM is 0.90 , while the spatial correlation is 0.85 . In the summer monsoon season (i.e., May, June, and July), both runs show the highest temporal correlations with observation but the lowest in the spatial correlations. The comparisons show that simulated rainfall generally agrees with the observation in space and time, especially when ERA-Interim reanalysis is used (i.e., in ERA_FINN).

The representative wind pattern in Southeast Asia is the monsoon wind flow. In the winter monsoon season (i.e., February, March, and April), mean surface winds are from the northeast in the Northern Hemisphere and turn to the northwesterly once past the Equator (Fig. S3a). On the other hand, the wind directions are reversed in the summer monsoon season (i.e., August, September, and October) (Fig. S3b). We use the wind data from NCEP-FNL and ERAInterim reanalysis to evaluate model-simulated winds. We find that both runs overestimated the $u$ component (stronger easterly) in the South China Sea (Fig. S4a and c) in the
Table 4. The spatial and temporal correlation of monthly rainfall between models (FNL_FINN and ERA_FINN) and observation (TRMM) during 2003-2014. FMA, MJJ, ASO, NDJ, and All represent February-April, May-July, August-October, NovemberJanuary, and the whole year, respectively.

\begin{tabular}{lccccc}
\hline & \multicolumn{2}{c}{ FNL_FINN vs. TRMM } & & \multicolumn{2}{c}{ ERA_FINN vs. TRMM } \\
\cline { 2 - 3 } \cline { 6 - 6 } & $\begin{array}{c}\text { Spatial } \\
\text { cor. }\end{array}$ & $\begin{array}{c}\text { Temporal } \\
\text { cor. }\end{array}$ & & $\begin{array}{c}\text { Spatial } \\
\text { cor. }\end{array}$ & $\begin{array}{c}\text { Temporal } \\
\text { cor. }\end{array}$ \\
\hline FMA & 0.89 & 0.61 & & 0.89 & 0.89 \\
MJJ & 0.83 & 0.69 & & 0.81 & 0.90 \\
ASO & 0.86 & 0.59 & & 0.84 & 0.89 \\
NDJ & 0.88 & 0.60 & & 0.88 & 0.85 \\
\hline All & 0.86 & 0.68 & & 0.85 & 0.90 \\
\hline
\end{tabular}

winter monsoon season, and overestimated the $v$ component (stronger southerly) in Java Sea in the summer monsoon season (Fig. S4b and d). These regions are the entrances of mon- 
soon wind flow into the MC. In general, the model has captured well the general wind flows in Southeast Asia during both monsoon seasons but overestimated about $1 \mathrm{~m} \mathrm{~s}^{-1}$ in wind speed in some regions likely due to terrain effect and model resolution limitation.

When comparing two of our simulations, FNL_FINN and ERA_FINN, we find that the ERA_FINN run consistently produces less precipitation than the FNL_FINN run during the rainy seasons over the past decade (Fig. 2). Regarding fire aerosol life cycle, less rainfall in ERA_FINN results in weaker wet scavenging and thus higher abundance of fire aerosols than in FNL_FINN. We find that the annual mean concentration of fire $\mathrm{PM}_{2.5}$ produced in the ERA_FINN run in Bangkok, Kuala Lumpur, Singapore, and Kuching is 9.2, $5.8,3.4$, and $7.7 \mu \mathrm{g} \mathrm{m}^{-3}$, respectively, clearly higher than the corresponding results of the FNL_FINN run of 8.5, 5.3, 3.0, and $6.9 \mu \mathrm{g} \mathrm{m}^{-3}$ (Table 3). In general, fire $\mathrm{PM}_{2.5}$ concentration in ERA_FINN is about $10 \%$ higher than in FNL_FINN. However, the occurrence of low-visibility events is less sensitive to the differences in rainfall in places near the burning areas such as Bangkok and Kuching, as indicated by a nearly negligible enhancement of VLVDs in the ERA_FINN run in Bangkok and Kuching $(\sim 1 \%)$ (Table 2$)$. In comparison, the difference in wind fields between the two runs has a much smaller impact than that of precipitation on modeled particulate matter abundance.

\subsection{Different biomass burning emission inventories}

In addition to meteorological inputs, using different fire emission estimates could also affect the modeled $\mathrm{PM}_{2.5}$ concentration. To examine this impact, we have compared two simulations with the same meteorological input but different fire emission inventories, the FNL_FINN using FINNv1.5 and FNL_GFED using GFEDv4.1s. The main differences between the two emission inventories appear mostly in mainland Southeast Asia (s1) and northern Australia (s5) (Fig. 2a and e). Compared to FINNv1.5, fire emissions in GFEDv4.1s over mainland Southeast Asia are more than $66 \%$ lower (Fig. 2a), and this results in a $43 \%$ lower fire $\mathrm{PM}_{2.5}$ concentration in Bangkok (Table 3). The lower fire $\mathrm{PM}_{2.5}$ concentration in FNL_GFED actually produces a visibility that matches better with observations in Bangkok comparing to the result of FNL_FINN (Fig. S5a). This implies that the fire emissions in FINNv1.5 are perhaps overestimated in mainland Southeast Asia. In northern Australia, fire aerosol emissions suggested by FINNv1.5 are almost negligible compared to GFEDv4.1s (Fig. 2e). Therefore, in the FNL_GFED simulation, Australia fire aerosols play an important role in Singapore air quality, contributing to about $22 \%$ of the modeled $\mathrm{PM}_{2.5}$ concentration in Singapore. In contrast, Australia fires have nearly no effect on Singapore air quality in the FNL_FINN run (Table 3).

We would also like to point out the importance of spatiotemporal distribution of fire emission to the modeled
$\mathrm{PM}_{2.5}$ concentration. For example, during the June 2013 severe haze event in Kuala Lumpur and Singapore, the total amount of fire emissions from Sumatra (s2) in GFEDv4.1s is lower than that of FINNv1.5 (Fig. S6a) but distributed more densely over a smaller area (Fig. S6c and d). As a result, under the same meteorological conditions, the simulated $\mathrm{PM}_{2.5}$ in the FNL_GFED simulation reaches Singapore in a higher concentration that also matches better with observations than the result of FNL_FINN (Fig. S6b).

Reddington et al. (2014) applied two different models, a 3D global chemical transport model and a Lagrangian tracer model to examine the long-term mean contributions of fire emissions from different regions to $\mathrm{PM}_{2.5}$ in several cities in Southeast Asia. Their estimated contribution from mainland Southeast Asia to the above-discussed four selected cities in Sect. 3.1 was lower than our result during January-May, likely due to their use of a different emission inventory and the coarse resolution of their global model. The FINNv1.5 dataset used in our study specifically provides higher $\mathrm{PM}_{2.5}$ emissions from agriculture fires (the major fire type in mainland Southeast Asia) than GFED4.1s does - the latter is an updated version of the dataset (GFEDv3) used in Reddington et al. (2014) (Fig. 2).

\section{Summary and conclusions}

We have examined the extent of the biomass burning aerosol's impact on the air quality of Southeast Asia over the past decade using surface visibility and $\mathrm{PM}_{2.5}$ measurements along with the WRF model with a modified fire tracer module. The model has shown a good performance in capturing $90 \%$ of the observed severe haze events (visibility $<7 \mathrm{~km}$ ) caused by fire aerosols over the past decade in several cities that are close to the major burning sites. Our study also suggests that fire aerosols are responsible for a substantial fraction of the low-visibility days (visibility $<10 \mathrm{~km}$ ) in these cities: up to $39 \%$ in Bangkok, $36 \%$ in Kuala Lumpur, $34 \%$ in Singapore, and $33 \%$ in Kuching.

In attributing the low-visibility events to fire emissions from different sites, we find that mainland Southeast Asia is the major contributor during the northeast or winter monsoon season in Southeast Asia. In the southwest or summer monsoon season, however, most fire aerosols come from Sumatra and Borneo. Specifically, fires in mainland Southeast Asia account for the largest percentage of the total fire $\mathrm{PM}_{2.5}$ in Bangkok (99\%), and fires from Sumatra are the major contributor in Kuala Lumpur $(50 \%)$ and Singapore $(41 \%)$. Kuching receives $85 \%$ of fire aerosols from local Borneo fires.

By comparing the results from two modeled runs with the same fire emissions but driven by different meteorological inputs, we have examined the sensitivity of modeled results to meteorological datasets. The discrepancy in modeled lowvisibility events arising from the use of different meteoro- 
logical datasets is clearly evident, especially in the results of Bangkok and Kuching. However, using different meteorological input datasets does not appear to have influenced the modeled very low-visibility events, or the severe haze events in the cities close to burning sites.

We have also examined the sensitivity of modeled results to the use of different emission inventories. We find that significant discrepancies of fire emissions in mainland Southeast Asia and northern Australia between the two emission inventories used in our study have caused a substantial difference in modeled fire aerosol concentration and visibility, especially in Bangkok and Singapore. For instance, the contribution to fire aerosol in Singapore from northern Australia changes from nearly zero in the simulation driven by FINNv1.5 to about $22 \%$ in another simulation driven by GFEDv4.1s. Based on these results, we suggest further research is needed to improve the current estimate of the spatiotemporal distribution of fire emissions, in addition to total emitted quantities from the fire hotspots.

To further assess the impacts of particulate pollution on the surface visibility of the whole of Southeast Asia and to estimate the fire aerosol's contribution, we have defined and derived a metric of "haze exposure days" (HEDs), by integrating annual low-visibility days of 50 cities of the Association of Southeast Asian Nations and weighted by population or averaged arithmetically. We find that a very large population of Southeast Asia has been exposed to relatively persistent hazy conditions. The top four cities in the HED ranking, Jakarta, Bangkok, Hanoi, and Yangon, with a total population exceeding 30 million, all have experienced more than 200 days per year of low visibility due to particulate pollution over the past decade and more than $50 \%$ of those low-visibility days were mainly due to fire aerosols. Even worse is that the number of annual low-visibility days have been increasing steadily not only in high-population cities but also those with relatively low populations, suggesting widespread particulate pollution across Southeast Asia. In summary, the fire aerosols are found to be responsible for up to about half of the total exposures to low visibility in the region. This result suggests that in order to improve the air quality in Southeast Asia, besides reducing or even prohibiting planned or unplanned fires, mitigation policies targeting pollution sources other than fires also need to be implemented.

\section{Data availability}

GFEDv4.1s emission data are publicly available from the GFED website and can be downloaded from http://www.globalfiredata.org/data.html. FINNv1.5 emission can be obtained from http://bai.acom.ucar.edu/Data/fire/. The observational visibility from the GSOD can be downloaded from https://data.noaa.gov/dataset/ global-surface-summary-of-the-day-gsod. WRF simu- lated data are available upon request from Hsiang-He Lee (hsiang-he@ smart.mit.edu).

\section{The Supplement related to this article is available online at doi:10.5194/acp-17-965-2017-supplement.}

Acknowledgement. This research was supported by the National Research Foundation Singapore through the Singapore-MIT Alliance for Research and Technology, the interdisciplinary research program of the Center for Environmental Sensing and Modeling. It was also supported by the US National Science Foundation (AGS-1339264), US DOE (DE-FG02-94ER61937) and US EPA (XA-83600001-1). The authors would like to acknowledge the National Environment Agency (NEA) of Singapore for making Singapore $\mathrm{PM}_{2.5}$ data available; the NCEP-FNL, ECMWF ERAInterim, NCAR FINN, and GFED working groups for releasing their data to the research communities; and the NCAR WRF developing team for providing the numerical model for this study. We thank the National Supercomputing Centre of Singapore (NSCC) for providing computing resources and technical support. Two anonymous reviewers provided many constructive suggestions and comments, leading to a substantial improvement of the paper.

Edited by: D. Spracklen

Reviewed by: two anonymous referees

\section{References}

Carlson, K. M., Curran, L. M., Ratnasari, D., Pittman, A. M., Soares-Filho, B. S., Asner, G. P., Trigg, S. N., Gaveau, D. A., Lawrence, D., and Rodrigues, H. O.: Committed carbon emissions, deforestation, and community land conversion from oil palm plantation expansion in West Kalimantan, Indonesia, P. Natl. Acad. Sci. USA, 109, 7559-7564, doi:10.1073/pnas.1200452109, 2012.

Chang, C. P., Wang, Z., McBride, J., and Liu, C.-H.: Annual Cycle of Southeast Asia-Maritime Continent Rainfall and the Asymmetric Monsoon Transition, J. Climate, 18, 287-301, doi:10.1175/JCLI-3257.1, 2005.

Crippa, P., Castruccio, S., Archer-Nicholls, S., Lebron, G. B., Kuwata, M., Thota, A., Sumin, S., Butt, E., Wiedinmyer, C., and Spracklen, D. V.: Population exposure to hazardous air quality due to the 2015 fires in Equatorial Asia, Scient. Rep., 6, 37074, doi:10.1038/srep37074, 2016.

Dennis, R., Mayer, J., Applegate, G., Chokkalingam, U., Colfer, C. P., Kurniawan, I., Lachowski, H., Maus, P., Permana, R., Ruchiat, Y., Stolle, F., Suyanto, and Tomich, T.: Fire, People and Pixels: Linking Social Science and Remote Sensing to Understand Underlying Causes and Impacts of Fires in Indonesia, Hum. Ecol., 33, 465-504, doi:10.1007/s10745-005-5156-z, 2005.

Emmanuel, S. C.: Impact to lung health of haze from forest fires: The Singapore experience, Respirology, 5, 175-182, doi:10.1046/j.1440-1843.2000.00247.x, 2000. 
European Centre for Medium-Range Weather Forecasts: ERAInterim Project, UCAR/NCAR - Research Data Archive, doi:10.5065/D6CR5RD9, 2009.

Field, R. D., van der Werf, G. R., and Shen, S. S. P.: Human amplification of drought-induced biomass burning in Indonesia since 1960, Nat. Geosci., 2, 185-188, 2009.

Fujii, Y., Iriana, W., Oda, M., Puriwigati, A., Tohno, S., Lestari, P., Mizohata, A., and Huboyo, H. S.: Characteristics of carbonaceous aerosols emitted from peatland fire in Riau, Sumatra, Indonesia, Atmos. Environ., 87, 164-169, doi:10.1016/j.atmosenv.2014.01.037, 2014.

Giglio, L., Randerson, J. T., and van der Werf, G. R.: Analysis of daily, monthly, and annual burned area using the fourthgeneration global fire emissions database (GFED4), J. Geophys. Res.-Biogeo., 118, 317-328, doi:10.1002/jgrg.20042, 2013.

Grandey, B. S., Lee, H. H., and Wang, C.: Radiative effects of interannually varying vs. interannually invariant aerosol emissions from fires, Atmos. Chem. Phys., 16, 14495-14513, doi:10.5194/acp-16-14495-2016, 2016.

Grell, G. A., Peckham, S. E., Schmitz, R., McKeen, S. A., Frost, G., Skamarock, W. C., and Eder, B.: Fully coupled "online" chemistry within the WRF model, Atmos. Environ., 39, 6957-6975, doi:10.1016/j.atmosenv.2005.04.027, 2005.

Grell, G. A., Freitas, S. R., Stuefer, M., and Fast, J.: Inclusion of biomass burning in WRF-Chem: impact of wildfires on weather forecasts, Atmos. Chem. Phys., 11, 5289-5303, doi:10.5194/acp11-5289-2011, 2011.

Heil, A., Langmann, B., and Aldrian, E.: Indonesian peat and vegetation fire emissions: Study on factors influencing largescale smoke haze pollution using a regional atmospheric chemistry model, Mitig. Adapt. Strat. Glob. Change, 12, 113-133, doi:10.1007/s11027-006-9045-6, 2007.

Huffman, G. J., Bolvin, D. T., Nelkin, E. J., Wolff, D. B., Adler, R. F., Gu, G., Hong, Y., Bowman, K. P., and Stocker, E. F.: The TRMM Multisatellite Precipitation Analysis (TMPA): Quasi-Global, Multiyear, Combined-Sensor Precipitation Estimates at Fine Scales, J. Hydrometeorol., 8, 38-55, doi:10.1175/JHM560.1, 2007.

IEA: Energy and Climate Change, World Energy Outlook Special Report, International Energy Agency, IEA online archive, 74-77, 2015.

Johnston, F. H., Henderson, S. B., Chen, Y., Randerson, J. T., Marlier, M., Defries, R. S., Kinney, P., Bowman, D. M., and Brauer, M.: Estimated global mortality attributable to smoke from landscape fires, Environ. Health Perspect., 120, 695-701, 2012.

Kiehl, J. T., Schneider, T. L., Rasch, P. J., Barth, M. C., and Wong, J.: Radiative forcing due to sulfate aerosols from simulations with the National Center for Atmospheric Research Community Climate Model, Version 3, J. Geophys. Res.-Atmos., 105, 14411457, doi:10.1029/1999JD900495, 2000.

Kim, D., Wang, C., Ekman, A. M. L., Barth, M. C., and Rasch, P. J.: Distribution and direct radiative forcing of carbonaceous and sulfate aerosols in an interactive size-resolving aerosol-climate model, J. Geophys. Res.-Atmos., 113, D16309, doi:10.1029/2007jd009756, 2008.

Koe, L. C. C., Arellano Jr., A. F., and McGregor, J. L.: Investigating the haze transport from 1997 biomass burning in Southeast Asia: its impact upon Singapore, Atmos. Environ., 35, 27232734, doi:10.1016/S1352-2310(00)00395-2, 2001.
Kunii, O., Kanagawa, S., Yajima, I., Hisamatsu, Y., Yamamura, S., Amagai, T., and Ismail, I. T. S.: The 1997 Haze Disaster in Indonesia: Its Air Quality and Health Effects, Arch. Environ. Health, 57, 16-22, doi:10.1080/00039890209602912, 2002.

Langner, A., Miettinen, J., and Siegert, F.: Land cover change 2002 2005 in Borneo and the role of fire derived from MODIS imagery, Global Change Biol., 13, 2329-2340, doi:10.1111/j.13652486.2007.01442.x, 2007.

Lin, N.-H., Tsay, S.-C., Maring, H. B., Yen, M.-C., Sheu, G.-R., Wang, S.-H., Chi, K. H., Chuang, M.-T., Ou-Yang, C.-F., Fu, J. S., Reid, J. S., Lee, C.-T., Wang, L.-C., Wang, J.-L., Hsu, C. N., Sayer, A. M., Holben, B. N., Chu, Y.-C., Nguyen, X. A., Sopajaree, K., Chen, S.-J., Cheng, M.-T., Tsuang, B.-J., Tsai, C.J., Peng, C.-M., Schnell, R. C., Conway, T., Chang, C.-T., Lin, K.-S., Tsai, Y. I., Lee, W.-J., Chang, S.-C., Liu, J.-J., Chiang, W.-L., Huang, S.-J., Lin, T.-H., and Liu, G.-R.: An overview of regional experiments on biomass burning aerosols and related pollutants in Southeast Asia: From BASE-ASIA and the Dongsha Experiment to 7-SEAS, Atmos. Environ., 78, 1-19, doi:10.1016/j.atmosenv.2013.04.066, 2013.

Madden, R. A. and Julian, P. R.: Detection of a 4050 Day Oscillation in the Zonal Wind in the Tropical Pacific, J. Atmos. Sci., 28, 702-708, doi:10.1175/15200469(1971)028<0702:DOADOI>2.0.CO;2, 1971.

Marlier, M., Defries, R. S., Kim, P. S., Koplitz, S. N., Jacob, D. J., Mickley, L. J., and Myers, S. S.: Fire emissions and regional air quality impacts from fires in oil palm, timber, and logging concessions in Indonesia, Environ. Res. Lett., 10, 085005, doi:10.1088/1748-9326/10/8/085005, 2015a.

Marlier, M. E., DeFries, R. S., Kim, P. S., Gaveau, D. L. A., Koplitz, S. N., Jacob, D. J., Mickley, L. J., Margono, B. A., and Myers, S. S.: Regional air quality impacts of future fire emissions in Sumatra and Kalimantan, Environ. Res. Lett., 5, 054010, doi:10.1088/1748-9326/10/5/054010, 2015b.

Mauderly, J. L. and Chow, J. C.: Health effects of organic aerosols, Inhalat. Toxicol., 20, 257-288, 2008.

McBride, J. L., Haylock, M. R., and Nicholls, N.: Relationships between the Maritime Continent Heat Source and the El NiñoSouthern Oscillation Phenomenon, J. Climate, 16, 2905-2914, doi:10.1175/1520-0442(2003)016<2905:RBTMCH>2.0.CO;2, 2003.

National Centers for Environmental Prediction: NCEP FNL Operational Model Global Tropospheric Analyses, continuing from July 1999, doi:10.5065/D6M043C6, 2000.

Page, S. E., Siegert, F., Rieley, J. O., Boehm, H.-D. V., Jaya, A., and Limin, S.: The amount of carbon released from peat and forest fires in Indonesia during 1997, Nature, 420, 61-65, 2002.

Randerson, J. T., Chen, Y., van der Werf, G. R., Rogers, B. M., and Morton, D. C.: Global burned area and biomass burning emissions from small fires, J. Geophys. Res.-Biogeo., 117, G04012, doi:10.1029/2012JG002128, 2012.

Rasmusson, E. M. and Wallace, J. M.: Meteorological Aspects of the El Niño/Southern Oscillation, Science, 222, 1195-1202, doi:10.1126/science.222.4629.1195, 1983.

Reddington, C. L., Yoshioka, M., Balasubramanian, R., Ridley, D., Toh, Y. Y., Arnold, S. R., and Spracklen, D. V.: Contribution of vegetation and peat fires to particulate air pollution in Southeast Asia, Environ. Res. Lett., 9, 094006, doi:10.1088/17489326/9/9/094006, 2014. 
Reid, J. S., Xian, P., Hyer, E. J., Flatau, M. K., Ramirez, E. M., Turk, F. J., Sampson, C. R., Zhang, C., Fukada, E. M., and Maloney, E. D.: Multi-scale meteorological conceptual analysis of observed active fire hotspot activity and smoke optical depth in the Maritime Continent, Atmos. Chem. Phys., 12, 2117-2147, doi:10.5194/acp-12-2117-2012, 2012.

Reid, J. S., Lagrosas, N. D., Jonsson, H. H., Reid, E. A., Sessions, W. R., Simpas, J. B., Uy, S. N., Boyd, T. J., Atwood, S. A., Blake, D. R., Campbell, J. R., Cliff, S. S., Holben, B. N., Holz, R. E., Hyer, E. J., Lynch, P., Meinardi, S., Posselt, D. J., Richardson, K. A., Salinas, S. V., Smirnov, A., Wang, Q., Yu, L., and Zhang, J.: Observations of the temporal variability in aerosol properties and their relationships to meteorology in the summer monsoonal South China Sea/East Sea: the scale-dependent role of monsoonal flows, the Madden-Julian Oscillation, tropical cyclones, squall lines and cold pools, Atmos. Chem. Phys., 15, 1745-1768, doi:10.5194/acp-15-1745-2015, 2015.

Saji, N. H., Goswami, B. N., Vinayachandran, P. N., and Yamagata, T.: A dipole mode in the tropical Indian Ocean, Nature, 401, 360363, 1999

See, S. W., Balasubramanian, R., and Wang, W.: A study of the physical, chemical, and optical properties of ambient aerosol particles in Southeast Asia during hazy and nonhazy days, J. Geophys. Res.-Atmos., 111, D10S08, doi:10.1029/2005JD006180, 2006.

Seinfeld, J. and Pandis, S.: Atmospheric Physics and Chemistry. From Air Pollution to Climate Change, 2nd Edn., John Wiley \& Sons, New York, NY, 2006.

Sekiguchi, M., Nakajima, T., Suzuki, K., Kawamoto, K., Higurashi, A., Rosenfeld, D., Sano, I., and Mukai, S.: A study of the direct and indirect effects of aerosols using global satellite data sets of aerosol and cloud parameters, J. Geophys. Res.-Atmos., 108, 4699, doi:10.1029/2002JD003359, 2003.

Smith, A., Lott, N., and Vose, R.: The Integrated Surface Database: Recent Developments and Partnerships, B. Am. Meteorol. Soc., 92, 704-708, doi:10.1175/2011BAMS3015.1, 2011.
Stauffer, D. R. and Seaman, N. L.: Multiscale Four-Dimensional Data Assimilation, J. Appl. Meteorol., 33, 416-434, doi:10.1175/1520-0450(1994)033<0416:mfdda>2.0.co;2, 1994.

Tosca, M. G., Randerson, J. T., Zender, C. S., Nelson, D. L., Diner, D. J., and Logan, J. A.: Dynamics of fire plumes and smoke clouds associated with peat and deforestation fires in Indonesia, J. Geophys. Res.-Atmos., 116, D08207, doi:10.1029/2010JD015148, 2011.

van der Werf, G. R., Randerson, J. T., Giglio, L., Collatz, G. J., Mu, M., Kasibhatla, P. S., Morton, D. C., DeFries, R. S., Jin, Y., and van Leeuwen, T. T.: Global fire emissions and the contribution of deforestation, savanna, forest, agricultural, and peat fires (19972009), Atmos. Chem. Phys., 10, 11707-11735, doi:10.5194/acp10-11707-2010, 2010.

Visscher, A. D.: Air Dispersion Modeling: Foundations and Applications, 1st Edn., John Wiley \& Sons, Inc., p. 49, 2013.

Wang, J., Ge, C., Yang, Z., Hyer, E. J., Reid, J. S., Chew, B.-N., Mahmud, M., Zhang, Y., and Zhang, M.: Mesoscale modeling of smoke transport over the Southeast Asian Maritime Continent: Interplay of sea breeze, trade wind, typhoon, and topography, Atmos. Res., 122, 486-503, doi:10.1016/j.atmosres.2012.05.009, 2013.

Wiedinmyer, C., Akagi, S. K., Yokelson, R. J., Emmons, L. K., A1Saadi, J. A., Orlando, J. J., and Soja, A. J.: The Fire INventory from NCAR (FINN): a high resolution global model to estimate the emissions from open burning, Geosci. Model Dev., 4, 625641, doi:10.5194/gmd-4-625-2011, 2011.

$\mathrm{Wu}$, C.-H. and Hsu, H.-H.: Topographic Influence on the MJO in the Maritime Continent, J. Climate, 22, 5433-5448, doi:10.1175/2009JCLI2825.1, 2009.

Wu, R., Wen, Z., and He, Z.: ENSO Contribution to Aerosol Variations over the Maritime Continent and the Western North Pacific during 2000-10, J. Climate, 26, 6541-6560, doi:10.1175/JCLID-12-00253.1, 2013.

Zhang, C.: Madden-Julian Oscillation, Rev. Geophys., 43, RG2003, doi:10.1029/2004RG000158, 2005. 